\title{
Targeting platelet receptor function in thrombus formation: The risk of bleeding
}

Citation for published version (APA):

Swieringa, F., Kuijpers, M. J. E., Heemskerk, J. W. M., \& van der Meijden, P. E. J. (2014). Targeting platelet receptor function in thrombus formation: The risk of bleeding. Blood Reviews, 28(1), 9-21. https://doi.org/10.1016/j.blre.2013.12.001

Document status and date:

Published: 01/01/2014

DOI:

10.1016/j.blre.2013.12.001

Document Version:

Publisher's PDF, also known as Version of record

Document license:

Taverne

Please check the document version of this publication:

- A submitted manuscript is the version of the article upon submission and before peer-review. There can be important differences between the submitted version and the official published version of record.

People interested in the research are advised to contact the author for the final version of the publication, or visit the DOI to the publisher's website.

- The final author version and the galley proof are versions of the publication after peer review.

- The final published version features the final layout of the paper including the volume, issue and page numbers.

Link to publication

\footnotetext{
General rights rights.

- You may freely distribute the URL identifying the publication in the public portal. please follow below link for the End User Agreement:

www.umlib.nl/taverne-license

Take down policy

If you believe that this document breaches copyright please contact us at:

repository@maastrichtuniversity.nl

providing details and we will investigate your claim.
}

Copyright and moral rights for the publications made accessible in the public portal are retained by the authors and/or other copyright owners and it is a condition of accessing publications that users recognise and abide by the legal requirements associated with these

- Users may download and print one copy of any publication from the public portal for the purpose of private study or research.

- You may not further distribute the material or use it for any profit-making activity or commercial gain

If the publication is distributed under the terms of Article $25 \mathrm{fa}$ of the Dutch Copyright Act, indicated by the "Taverne" license above, 
REVIEW

\title{
Targeting platelet receptor function in thrombus formation: The risk of bleeding
}

\author{
Frauke Swieringa, Marijke J.E. Kuijpers, Johan W.M. Heemskerk*, Paola E.J. van der Meijden \\ Department of Biochemistry, CARIM, Maastricht University, Maastricht, The Netherlands
}

\section{A R T I C L E I N F O}

\section{Keywords:}

Antiplatelet drugs

Bleeding

Cardiovascular disease

Platelets

Thrombus

\begin{abstract}
A B S T R A C T
In this review, we presume that the process of thrombus formation, as assessed in whole blood flow studies and in experimental (murine) thrombosis studies, reflects the platelet responses in human haemostasis and thrombosis. Following this concept, we give an up-to-date overview of the main platelet receptors and signalling pathways that contribute to thrombus formation and are used as targets in (pre)clinical intervention studies to prevent cardiovascular disease. Discussed are receptors for thrombin, thromboxane, ADP, ATP, prostaglandins, von Willebrand factor, collagen, CLEC-2 ligand, fibrinogen and laminin. Sketched are the consequences of receptor deficiency or blockage for haemostasis and thrombosis in mouse and man. Recording of bleeding due to (congenital) platelet dysfunction or (acquired) antiplatelet treatment occurs according to different protocols, while common laboratory methods are used to determine platelet function.
\end{abstract}

(c) 2014 Elsevier Ltd. All rights reserved.

\section{Introduction}

Platelets are essential for normal haemostasis by forming a primary plug or thrombus after vascular injury, thus preventing further blood loss. Quantitative or qualitative platelet defects explain a considerable part of spontaneous or induced abnormal bleeding events in the population. Prospective studies suggest that the prevalence of bleeding due to platelet defects is high and comparable to that of von Willebrand disease [1]. Although the most severe platelet disorders are identified at childhood, the majority of patients with milder platelet disorders remain undiagnosed until excessive bleeding occurs after specific challenges, as in surgery or trauma. On the other hand, undesired platelet activation contributes to arterial thrombotic diseases, and antiplatelet medication is the common therapy for secondary prevention, as in cardiovascular disease and stroke. Risk of bleeding is a well-known side effect of this suppression of platelet activation.

The premise of this paper is that the process of thrombus formation, such as assessed in whole blood flow studies and in experimental (murine) thrombosis studies, mirrors the platelet responses that determine haemostasis and thrombosis. In this scenery, we aim to give an upto-date overview of the main platelet receptors and signalling pathways that contribute to thrombus formation and are used as targets in (pre) clinical intervention studies to attack cardiovascular disease. Since platelet dysfunction and treatment with antiplatelet therapy may both lead to a higher bleeding risk, we also sketch the current views of

\footnotetext{
* Corresponding author at: Department of Biochemistry, CARIM, P.O. Box 616, 6200 MD, Maastricht, The Netherlands. Tel.: +31 43 3881671; fax: + 31433884159.

E-mail address: jwm.heemskerk@maastrichtuniversity.nl (J.W.M. Heemskerk).
}

assessment of normal haemostasis by bleeding scores and discuss current methods to measure platelet function impairment.

\section{Platelet receptors, antagonists and thrombus formation}

\subsection{Thrombin receptors, PAR1, 3 and 4}

Thrombin, a short-living proteolytic enzyme generated from prothrombin by coagulation factor $\mathrm{Xa}$, is not only a strong platelet agonist, but also a main effector of the coagulation cascade, inducing fibrin clot formation [2]. Thrombin is generated at phosphatidylserine-exposing membranes from the damaged vessel wall and highly activated platelets [3]. Its formation and inactivation can precisely be measured in platelet-rich plasma or blood by thrombin generation assays [4]. Antithrombin in plasma binds and inactivates thrombin, a process that is enhanced by heparins.

In human platelets, thrombin cleaves and activates the proteaseactivated receptors (PAR) 1 and PAR4. In comparison to PAR4, the former displays a higher affinity to thrombin, transmitting signals at sub-nanomolar thrombin concentrations. Accordingly, PAR1 functions as the key thrombin receptor of human platelets, while PAR4 rather sustains the action of PAR1 [5]. Platelets do not express the factor Xa receptor, PAR2. Both expressed receptors, PAR1 and 4, signal via the Gproteins $\mathrm{G} 12 / 13 \alpha$ and $\mathrm{Gq} \alpha$, which evoke the majority of functional platelet responses (Fig. 1). Current view is that both thrombin receptors only indirectly signal via Gi $\alpha$, i.e. through ADP secretion and autocrine effects [6]. The PAR-induced activation of G12/13 $\alpha$ results in platelet shape change by activation of Rho-associated protein kinase (ROCK) followed by actin cytoskeletal changes, whereas the activation of $\mathrm{Gq} \alpha$ 


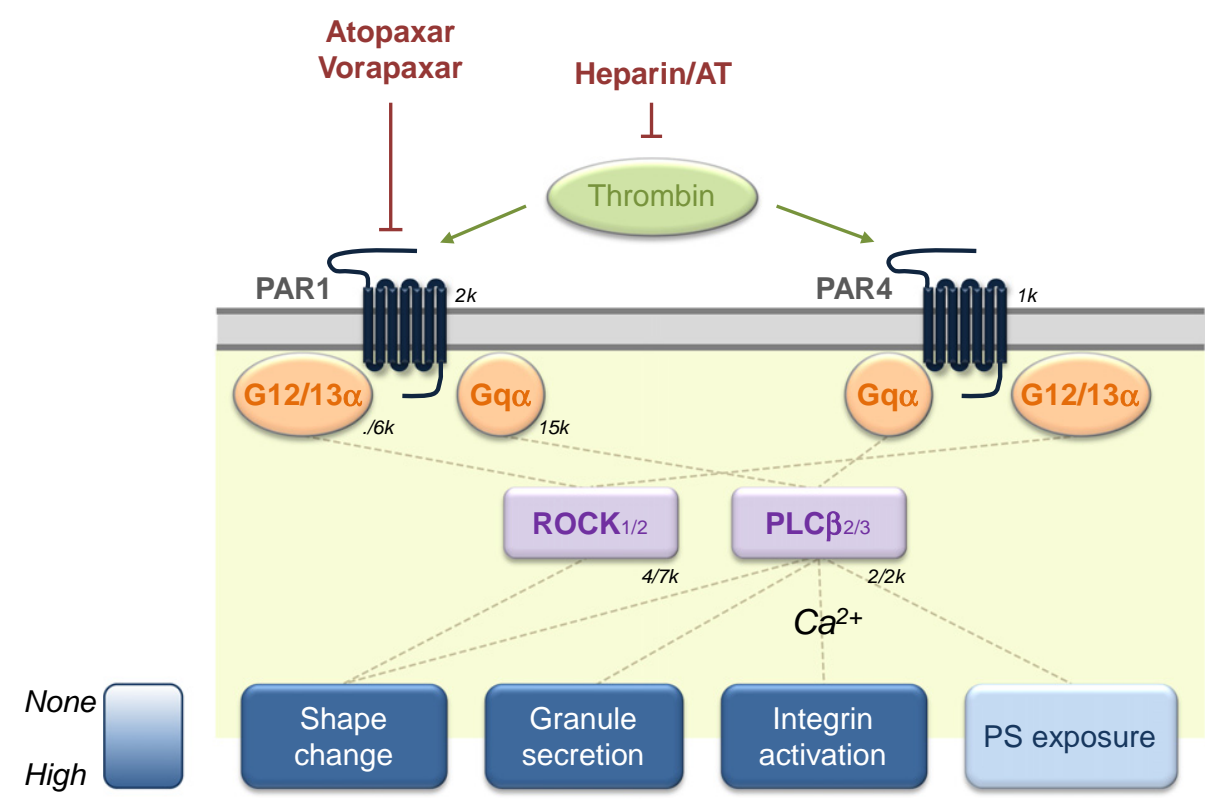

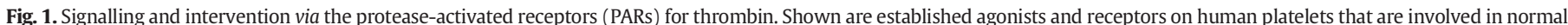

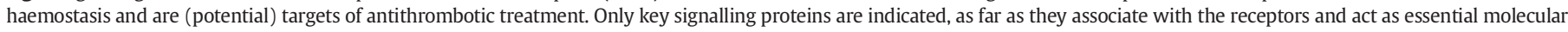

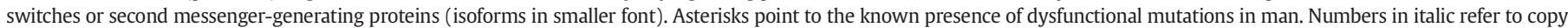

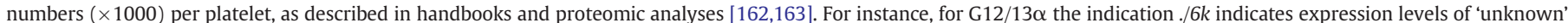

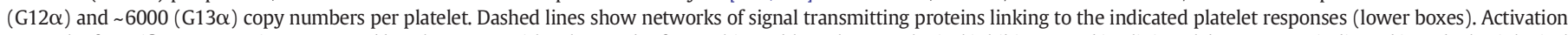

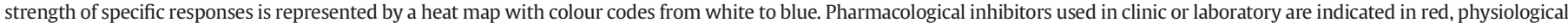
agonists in green. Abbreviations: AT, antithrombin; Gq, GTP-binding protein Gq; PLC, phospholipase C; PS, phosphatidylserine; ROCK, Rho-associated protein kinase.

results in $\mathrm{Ca}^{2+}$-dependent integrin $\alpha_{\mathrm{II}} \beta_{3}$ activation and secretion via the effector enzyme, phospholipase $C \beta$ (PLC $\beta$ ). Thrombin is a strong platelet agonist, which via PAR1/4 evokes maximal shape change, secretion and integrin activation, but thrombin by itself has little effect on platelet procoagulant activity (Fig. 1) [3]. In vitro, the various PAR receptors can be activated by specific thrombin receptor-activating peptides (TRAP). Patients with mutations in the genes encoding for PAR receptors have not yet been described, but a patient is reported with platelet $\mathrm{Gq} \alpha$ deficiency suffering from mucocutaneous bleeding [7].

Mouse platelets are devoid of PAR1 but express the isoform PAR3, which serves as thrombin-binding co-factor for PAR4 promoting the activity of this receptor [8]. Studies with $\mathrm{Par}^{-1-}$ and $\mathrm{Par}^{-1-}$ mice revealed marked protection in experimental arterial thrombosis, which was associated with prolonged bleeding times upon challenge [9]. In Par4 ${ }^{-1-}$ mice, thrombus formation in vivo was reduced compared to wildtypes, but knockout platelets showed normal adhesion and normal support of fibrin deposition [10]. These in vivo observations suggest a beneficial effect of blocking thrombin receptors in platelets.

In accordance with a key role of PAR1 in human platelet activation, clinical trials have been performed with PAR1 antagonists like Vorapaxar and Atopaxar. Vorapaxar has been evaluated in two phase III clinical trials. The TRACER study did not reveal superiority of Vorapaxar over standard therapy in the primary endpoint, which was a composite of death from cardiovascular causes, myocardial infarction, stroke, recurrent ischemia with rehospitalization, or urgent coronary revascularization [11]. In the TRA-2P TIMI-50 study, where patients with prior stroke were excluded, Vorapaxar was superior to placebo on top of standard care $[12,13]$. This benefit was at the expense of an increased risk of intracranial bleeding, which was observed in both studies. The other PAR1 antagonist, Atopaxar, has been tested in several phase II trials, showing similar outcomes as Vorapaxar in terms of safety and efficacy [14].

One consideration for the clinical practice, when prescribing PAR1 antagonists in combination with other antiplatelet agents is that, although an extra bleeding risk would be acceptable in comparison to gained antithrombotic protection, the patients need to take even more medication at extra costs, with lower compliance as a side effect [15].

\subsection{Thromboxane-prostanoid receptor, TP}

The TP receptor (one gene product, previously split into $\alpha$ and $\beta$ forms) is activated by the fatty acid derivative, thromboxane $A_{2}$ [16]. This prostanoid is released from activated platelets as a very unstable metabolite, hence providing a rapid shut-off action mechanism upon stimulation of the TP receptors. Thromboxane $A_{2}$ formation requires the release of arachidonic acid from membrane phospholipids, a process catalysed by the $\mathrm{Ca}^{2+}$-dependent cytosolic phospholipase $\mathrm{A}_{2}$. Arachidonate acts as a substrate for cyclooxygenase 1 (COX1) to produce prostaglandin $\mathrm{H}_{2}$, which is converted by thromboxane synthase into thromboxane $A_{2}$. Signalling via the TP receptor takes place via $\mathrm{G} 12 / 13 \alpha$ and $\mathrm{Gq} \alpha$, similarly as for thrombin, but at a lower extent (Fig. 2) [17]. Activation of G12/13 $\alpha$ again triggers platelet shape change via $\mathrm{ROCK}$ activation, while the low activation of $\mathrm{Gq} \alpha / \mathrm{PLC} \beta$ is still sufficient for integrin activation and secretion.

In the laboratory, the stable thromboxane analogue U46619 is used to specifically trigger TP receptors. By itself, U46619 is a weak agonist evoking limited functional responses, but it enhances the effects of other platelet agonists. In agreement with this, collageninduced platelet activation relies for a considerable extent on the release of thromboxane $\mathrm{A}_{2}$ and $\mathrm{ADP}$, and ensuing TP and $\mathrm{P} 2 \mathrm{Y}_{12}$ receptor activation, respectively [18]. The few patients described with mutations in the thromboxane receptor experience mild bleeding [7]. This agrees with the finding that also in $\mathrm{Tp}^{-1-}$ mice bleeding times are prolonged [19].

The COX1 complex is irreversibly inhibited by Aspirin and other non-steroid anti-inflammatory drugs (NSAIDs), such as Indomethacin, Diclofenac, Ibuprofen and Naproxen (Fig. 2). The classical test to check for inhibited COX1 activity is measurement of arachidonic acidinduced (i.e., thromboxane-dependent) platelet aggregation. Benefit of Aspirin in the treatment and secondary prevention of cardiovascular disease has clearly been shown in early clinical trials [20,21]. However, Aspirin has side effects experienced by some patients, particularly renal insufficiently, gastrointestinal symptoms and haemorrhagic complications [22]. In accordance with this, also patients with an inherited 


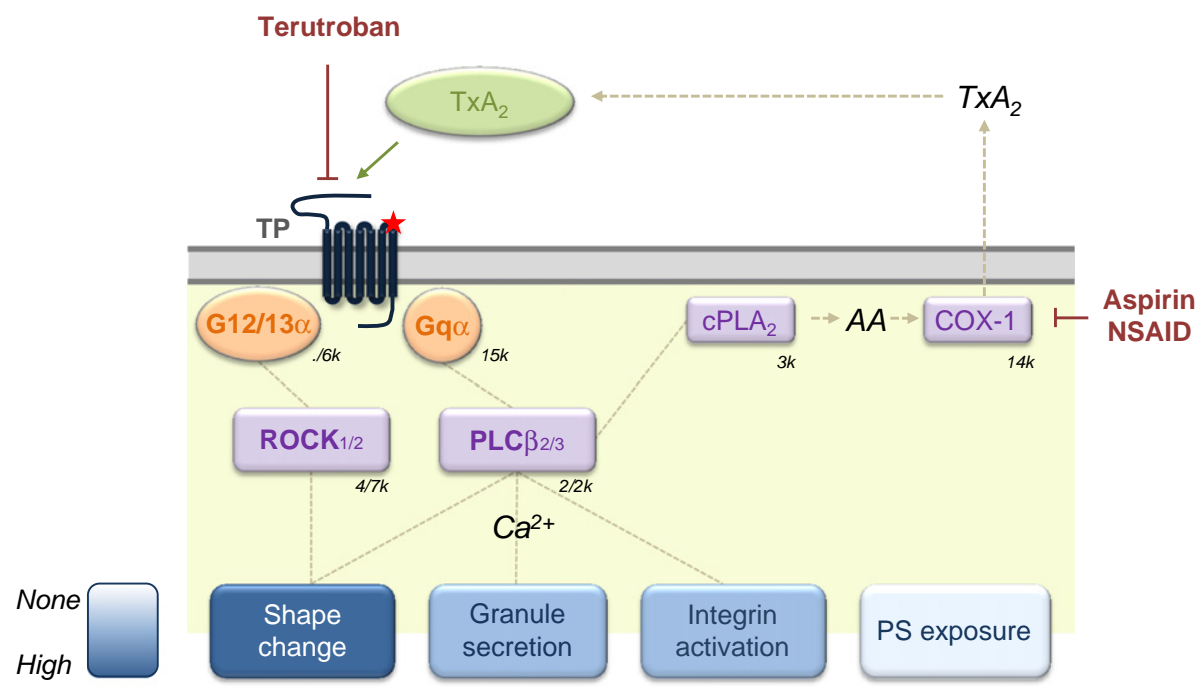

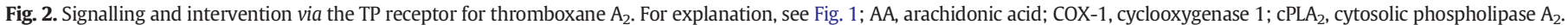

'aspirin-like' platelet defect frequently have a mild bleeding phenotype [7]. While biochemical 'resistance' to Aspirin intake (i.e., lack of inhibition of thromboxane $A_{2}$ formation) is relatively rare, the drug prevents only part of the thrombotic events [23], likely because thromboxane is a weak platelet agonist. Intake of other NSAIDs may increase the cardiovascular risk, indicating that such drugs also affect other processes than platelet thromboxane formation [24].

One of the developed antagonists for thromboxane receptors, Terutroban, has been tested clinically as an orally active drug. The TAIPAD study indicated that it was as effective as Aspirin in secondary prevention of thrombotic events in cardiovascular disease [25]. On the other hand, superiority of Terutroban over Aspirin could not be demonstrated in the PERFORM trial, in preventing arterial events in patients with stroke [26].

\subsection{Purinergic receptors, $P 2 Y_{1}, P 2 Y_{12}$ and $P 2 X_{1}$}

The platelet dense granules ( $\delta$-granules) contain high concentrations of the adenosine nucleotides ADP, ATP and adenosine polyphosphate. In response to physiological agonists, these nucleotides are secreted and enforce platelet activation processes in an autocrine manner. Secreted ADP interacts with the purinergic $\mathrm{P}_{2} \mathrm{Y}_{1}$ and $\mathrm{P}_{2} \mathrm{Y}_{12}$ receptors, while ATP binds to $\mathrm{P}_{2} \mathrm{X}_{1}$ receptors (Fig. 3 ). The receptors $\mathrm{P}_{2} \mathrm{Y}_{1}$ and $\mathrm{P}_{2} \mathrm{Y}_{12}$ are coupled to the G-proteins, Gq $\alpha$ and $\mathrm{Gi} \alpha$, respectively [27]. Interaction of ADP with $\mathrm{P}_{2} \mathrm{Y}_{1}$ results in $\mathrm{Ca}^{2+}$ mobilization, shape change and initial platelet aggregation through PLC $\beta$ stimulation [28]. Stimulation of the other receptor, $\mathrm{P}_{2} \mathrm{Y}_{12}$, promotes the formation of large and stable platelet aggregates [29]. The principal signalling mechanism of $\mathrm{P}_{2} \mathrm{Y}_{12}$ is by Gi $\alpha$-dependent stimulation of phosphoinositide 3-kinase (PI3K $\beta / \gamma)$, which regulates platelet aggregation via actin cytoskeleton-dependent integrin $\alpha_{I I b} \beta_{3}$ activation [30]. The alternative pathway of Gi $\alpha$ mediated inhibition of adenylate cyclase is nowadays considered to be of lesser importance [31]. Under flow, continuous signalling via P2Y 12 is required to maintain $\alpha_{\mathrm{IIb}} \beta_{3}$ in the active conformation, and to ensure thrombus stability [32].

Patients with $\mathrm{P}_{2} \mathrm{Y}_{1}$ deficiencies are not yet known. However, mice lacking this receptor on platelets are protected from collagen/ epinephrine-induced thromboembolism and have a bleeding phenotype $[28,33]$. The $\mathrm{P}_{2} \mathrm{Y}_{1}$-deficient platelets show reduced aggregation to all agonists. Conversely, mice with platelets overexpressing P2Y are more susceptible to thromboembolism and arterial thrombosis [34].

Thirteen patients, experiencing a mild bleeding diathesis, have been described who either lack $\mathrm{P}_{2} \mathrm{Y}_{12}$ receptors or have a receptor mutation interfering with ligand binding [29,35]. Platelets from these patients display a lesser and reversible aggregation in response to ADP, but have normal shape change and $\mathrm{Ca}^{2+}$ mobilization. Bleeding is also reported for subjects with heterozygous point mutations in the receptor locus [36]. Interestingly, reduced expression in platelets of the $\mathrm{P}^{2} \mathrm{Y}_{12}{ }^{-}$ transmitting protein Gi $\alpha$ gives a similar phenotype [7]. Also mice deficient in $\mathrm{P}_{2} \mathrm{Y}_{12}$ display defective ADP-induced platelet aggregation and increased bleeding times. In vivo, their platelets form small and unstable thrombi [37]. Conversely, transgenic mice expressing constitutively active $\mathrm{P}_{2} \mathrm{Y}_{12}$ exhibit increased platelet activation and arterial thrombosis [38].

As reviewed elsewhere, $\mathrm{P}_{2} \mathrm{Y}_{12}$ is the pharmacological target of a number of common antiplatelet agents [29]. Thienopyridines derived from the prodrugs Clopidogrel and Prasugrel inhibit $\mathrm{P}_{2} \mathrm{Y}_{12}$ in an irreversible way, whereas the drugs Ticagrelor and Cangrelor act as reversible P2 $\mathrm{Y}_{12}$ inhibitors. When taken orally, Clopidogrel and Prasugrel need to be converted by hepatic cytochrome P450 enzymes into active, unstable metabolites. Despite well proven efficacy in multiple clinical trials, the use of Clopidogrel has certain drawbacks [29]. The antiplatelet effect is delayed by the metabolic conversion of the prodrug, while its irreversible mode of action can be a problem if patients acutely need surgery. Furthermore, Clopidogrel has considerable inter-individual variability in responsiveness, which is clinically relevant since 'poor' responders may not be adequately protected from adverse cardiovascular events [39]. Poor responsiveness to Clopidogrel is associated with loss-of-function mutations of cytochrome P450 isoforms [40]. This variability in Clopidogrel responsiveness would argue for routine testing of platelet function for optimal care of patients [29], as suggested in a proof-of-concept trial [41]. The structural analogue Prasugrel is less critically dependent on cytochrome P450 enzymes for conversion into the active metabolite in comparison to Clopidogrel. Prasugrel intake leads to faster appearance of the active metabolite in the blood, and overall greater inhibition of $\mathrm{P}_{2} \mathrm{Y}_{12}$-dependent platelet functions with less intra-individual variation $[29,40]$. For both drugs, though, adequate dosing is important, as full $\mathrm{P}_{2} \mathrm{Y}_{12}$ receptor blockage causes a high bleeding risk.

The PLATO trial demonstrated that the drug Ticagrelor, which acts as an oral and reversible $\mathrm{P}_{2} \mathrm{Y}_{12}$ antagonist, induces a more consistent platelet inhibition and a greater antithrombotic efficacy, when compared to Clopidogrel, but still at the expense of bleeding [42]. Another reversible $\mathrm{P}_{2} \mathrm{Y}_{12}$ inhibitor in use is the drug Cangrelor, which is administrated intravenously. A recent meta-analysis suggests that Cangrelor and Clopidogrel are similarly effective in reducing ischemic endpoints after percutaneous coronary intervention [43]. 


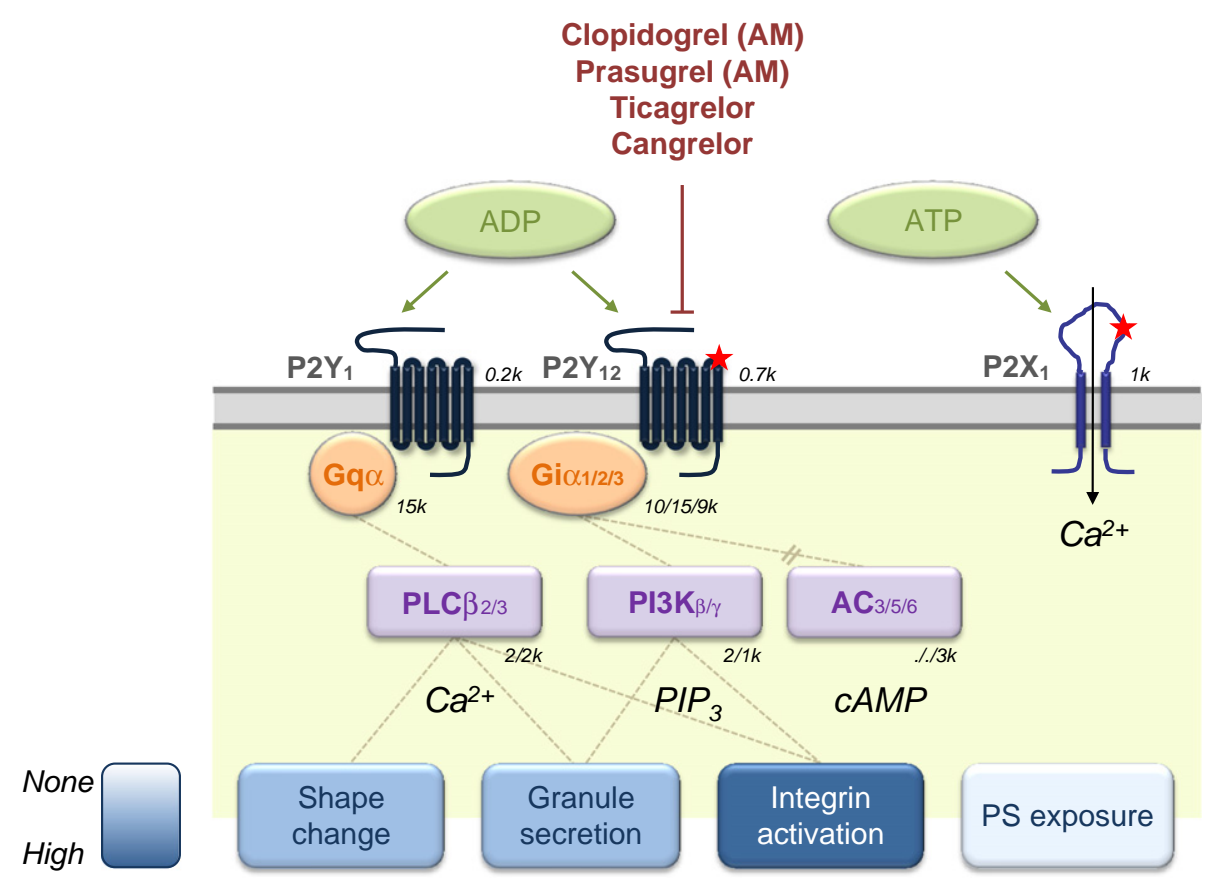

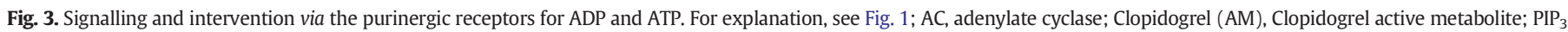
phosphatidylinositol 3-phosphate.

The ATP receptor $\mathrm{P} 2 \mathrm{X}_{1}$ operates as a cation channel that mediates transient $\mathrm{Ca}^{2+}$ influx through the plasma membrane and contributes to platelet activation by stimulating shape change (Fig. 3). The $\mathrm{Ca}^{2+}$ signal evoked by $\mathrm{P}_{2} \mathrm{X}_{1}$ synergizes with that of other receptors, thus explaining why $\mathrm{P}_{2} \mathrm{X}_{1}$ stimulation enhances platelet responses evoked by other agonists [44]. One case of a congenital deficiency in $\mathrm{P}_{2} \mathrm{X}_{1}$ activation has been presented that was accompanied by a bleeding diathesis [45]. Mice lacking $\mathrm{P}_{2} \mathrm{X}_{1}$ are viable, yet males are infertile $[46,47]$. $P 2 X_{1}$-deficient mice show impaired platelet aggregation at low agonist doses, decreased thrombus formation in vivo and protection from thromboembolism [47]. No specific drugs for clinical use have been described.

\subsection{Prostaglandin receptors, IP and EP1-4}

Prostaglandin $\mathrm{I}_{2}$ (prostacyclin) and prostaglandin $\mathrm{E}_{2}$ are prostanoids involved in haemostasis by interacting with the platelet IP and EP receptors, respectively. Next to nitric oxide, prostaglandin $\mathrm{I}_{2}$ is one of the major endothelium-derived platelet inhibitors. It abrogates platelet activation via the Gs $\alpha$-coupled IP receptors [48]. The signal pathway involves activation of the enzyme adenylyl cyclase, which raises the second messenger cyclic AMP and leads to protein phosphorylation events that are strongly inhibitory for platelets (Fig. 4). Several proteins integrate the inhibitory activities of cyclic AMP, in particularly the Gprotein regulators CalDAG-GEFI and RGS18 [49,50]. Mice lacking the IP receptor display an increased tendency to arterial thrombosis [51]. For the human IP receptor, dysfunctional mutations are known resulting in a defective function or lack of expression, which were more frequently accompanied by coronary artery obstruction, when compared to silent mutations [52]. Drugs targeting the IP receptor, such as Selexipag, Ilomedine and Teprostinil have primarily been tested for the treatment of pulmonary hypertension, but will also inhibit platelet function.

The vasodilatating prostaglandin $\mathrm{E}_{2}$ (as drug termed Dinoprostone) is released by various nuclear cells including macrophages. The mechanism by which prostaglandin $\mathrm{E}_{2}$ influences platelets is complex: it enhances platelet aggregation at low concentrations but inhibits at higher doses. The proaggregatory effect is mediated by prostaglandin $\mathrm{E}_{2}$ binding to the EP3 receptors and a Gi $\alpha$-linked mechanism (Fig. 4)
[53], similarly as described for ADP. It is suggested that EP3 signalling in this way contributes to ADP- and collagen-induced platelet aggregation at low agonist doses. Functional mutations in the human EP3 gene have not been described. Mice lacking this receptor display a markedly decreased susceptibility to prostaglandin $\mathrm{E}_{2}$-promoted thrombosis.

At higher concentrations, prostaglandin $\mathrm{E}_{2}$ binds to the EP1, EP2 and EP4 receptors [54]. All of these are Gs $\alpha$-coupled receptors, and thus inhibit platelets by increasing cyclic AMP levels [53]. In human platelets, especially the EP4 receptor transmits the inhibitory effect of prostaglandin $E_{2}$. A selective EP4 agonist such as ONO AE1-329 thus suppresses human platelet activation on collagen [55]. It was proposed that EP4 agonists can serve as antithrombotics, e.g. in cases where Aspirin and ADP antagonists alone are insufficient to prevent thrombotic events.

The EP3 receptor is of some interest as a target, e.g. in atherothrombotic disease where prostaglandin $\mathrm{E}_{2}$ levels are increased at sites of atherosclerotic lesions [56,57]. An EP3 antagonist at the beginning of clinical development (Phase II) is DG-041. Ex vivo, this compound inhibits the potentiating effects of prostaglandin $E_{2}$ on rat and human platelet aggregation induced by various agonists, in rat without increasing bleeding times $[57,58]$.

\subsection{Von Willebrand factor receptor, GPIb-V-IX}

Von Willebrand factor (VWF) is a large glycoprotein that is released from endothelial cells in blood plasma as well as from platelets. Ultralarge multimers (strings) of VWF freshly secreted by endothelial cells are most activating for platelets. Under normal conditions these strings are cleaved by the protease ADAMTS13, but when ADAMTS13 activity is absent they become clinically problematic causing thrombotic thrombocytopenia purpurea (TTP) [59]. Bleeding in TTP patients is considered to be a consequence of VWF-induced platelet agglutination and thrombocytopenia.

In healthy subjects VWF circulates as intermediate-size multimers, which capture factor VIII and bind to subendothelial matrix components (collagen, laminin) and platelet aggregates. Under high shear stress conditions as in the arterial circulation, the medium-sized VWF multimers change in conformation and avidly interact with the platelet GPIb-VIX complex, forming a so-called catch bond [60]. The consequence is 


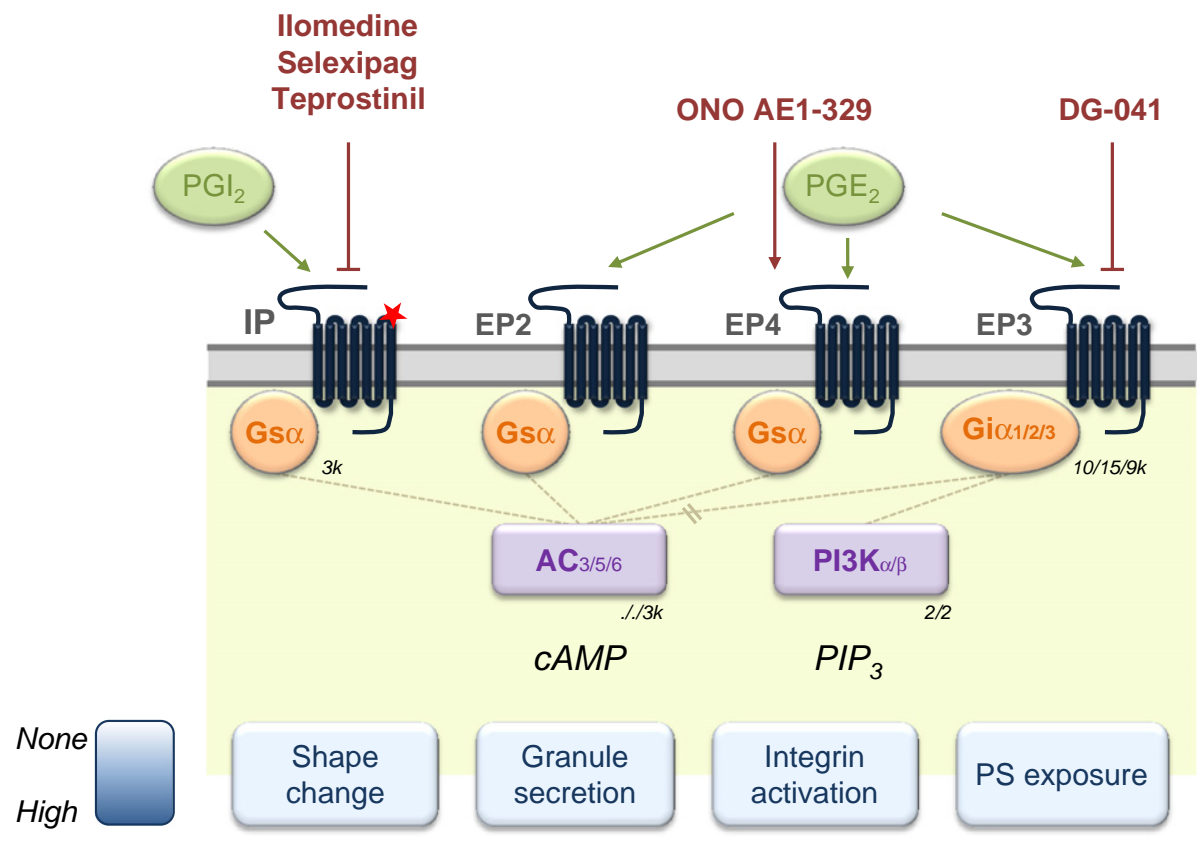

Fig. 4. Signalling and intervention via the prostaglandin IP and EP receptors. For explanation, see Fig. 1; PG, prostaglandin.

transient platelet adhesion which, in the presence of other receptorligand interactions (e.g. collagen), turns into firm adhesion and platelet activation under flow $[61,62]$. In the presence of high shear gradients, for instance at atherosclerotic geometries, platelets can form thrombi at post-stenotic sites in a GPIb-dependent manner with limited activation $[63,64]$.

In the laboratory, VWF-GPIb interaction is induced by the venom components ristocetin and botrocetin, which force VWF to bind to GPIb-V-IX in the absence of shear. Ristocetin- or shear-induced VWF-GPIb interaction leads to PLC $\gamma$ and PI3K activity and, thereby, ac-

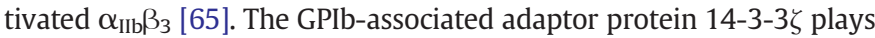
an intermediary role in assembly of the concerning signal complex [66]. The binding of VWF to GPIb-V-IX (under shear) induces only limited signalling events (Fig. 5). However, it enforces multiple amplification pathways in platelets, including thromboxane $A_{2}, A D P$ and phospholipase D pathways $[66,67]$.

There is increasing interest in the further roles of VWF and GPIb-VIX under conditions of coagulation and low shear, as in venous thrombosis. An initial observation was that thrombin binding to GPIb accelerates platelet activation via PAR1 [68]. Several other coagulation factors bind to the GPIb-V-IX complex as well, but the functional consequences are not well understood [3]. Under coagulant conditions, VWF binding to GPIb stimulates platelet procoagulant activity and the formation of fibrin fibres on human and mouse platelets [69]. This is compatible with the finding that in mice both VWF and GPIb contribute to venous thrombosis in vivo, although the precise mechanisms are not fully understood $[70,71]$. Together, this points to the existence of synergy pathways of GPIb- and coagulation (thrombin?)-mediated platelet responses.

Genetic deficiency or dysfunction of platelet GPIb-V-IX leads to Bernard-Soulier syndrome, a rare bleeding disorder characterized by thrombocytopenia and giant platelets [7]. A similar phenotype is observed in mice deficient in the GPIb $\alpha$ or GPIb $\beta$ chains [72,73]. Interestingly, also in mice, the GPV chain is considered to contribute to thrombus formation by acting as a cleavable substrate for thrombin [74]. The VWF-GPIb axis may also be a suitable target for pharmacological intervention. In baboons, the humanized anti-GPIb antibody h6B4 acts as a safe antithrombotic drug with minimal bleeding [75]. A second approach to interfere with GPIb-mediated thrombus formation may be to target VWF. It has been shown that antibodies against the $\mathrm{A} 3$ domain of vWF, through which GPIb interacts, inhibit arterial thrombus formation in vivo [76].

Bleeding is a recurrent phenomenon in patients with von Willebrand disease, a disorder characterized by quantitative or qualitative abnormalities in VWF [77]. In most forms of von Willebrand disease, ristocetininduced platelet clumping via VWF (so-called platelet agglutination) is reduced, thus stressing the importance of VWF-GPIb binding for normal haemostasis. In platelet-type $2 \mathrm{M}$ and type $2 \mathrm{~B}$ von Willebrand disease, the VWF-GPIb interaction is increased leading to 'spontaneous' platelet aggregation and even thrombocytopenia [77].

\subsection{Collagen receptor, GPVI}

The principal signalling receptor for collagen on platelets is glycoprotein VI (GPVI), a member of the immunoglobulin superfamily, which associates with the ITAM-bearing FcR $\gamma$-chain [78]. GPVI is only expressed on platelets and megakaryocytes, and it requires dimerization for binding to collagen [79]. Stimulation via GPVI leads to full platelet activation, including integrin activation, secretion and procoagulant activity [80]. Established ligands of GPVI are the fibrillar collagen types I or III, collagen-related peptides containing repeats of the sequence, glycineproline-hydroxyproline, and the snake venom convulxin.

The GPVI-induced signalling mechanism operates through protein tyrosine kinases, and resembles the signalling induced by various other adhesive receptors (Fig. 6) [81,82]. In brief, ligand-occupied GPVI dimers form a large signalling complex, via activation of Srcfamily kinases, phosphorylation of the ITAM motif of the FcR $\gamma$-chain, and activation of the central tyrosine kinase, Syk [83]. This results in a cascade of phosphorylation events, with as an end result the activation of key effector enzymes at the plasma membrane, PLC $\gamma$ and PI3K isoforms $[84,85]$. The functional consequences are prolonged $\mathrm{Ca}^{2+}$ mobilization, secretion, integrin activation, procoagulant activity and membrane blebbing (Fig. 7) [3]. The $\mathrm{Ca}^{2+}$-dependent proteins, protein kinase $C$ and CalDAG-GEFI, regulate many of the downstream responses to secretion and integrin activation (see below) [86,87].

The interest in GPVI as a target for antithrombotic therapy was greatly raised by the recognition that mice lacking the FcR $\gamma$-chain showed a greatly impaired thrombus formation in experimental models of arterial thrombosis, that was not accompanied by increased tail bleeding [88]. A similar phenotype was found after depletion of platelet 


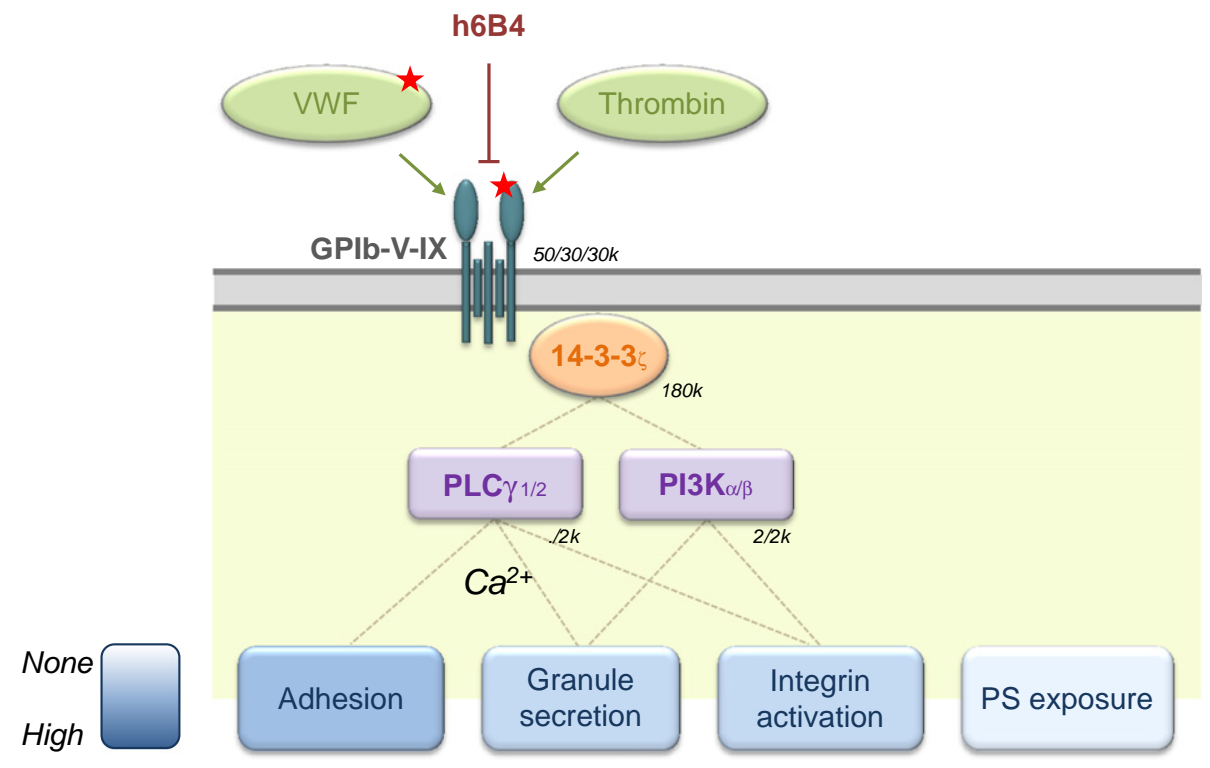

Fig. 5. Signalling and intervention via the von Willebrand factor (VWF) receptor, GPIb-V-IX. For explanation, see Fig. 1.

GPVI by injection of antibodies against this receptor [89]. In addition, blocking of GPVI impaired thrombus formation on atherosclerotic plaques, e.g. in a mouse model of acute plaque rupturing [90]. On the other hand, deficiency in GPVI did not affect arterial thrombus formation in models of more severe vascular damage with tissue factor exposure, where thrombin generation is considered to be the major driving force of thrombosis [91,92].

Several patients have been described with circulating anti-GPVI antibodies, accompanied by low expression of platelet GPVI, thrombocytopenia and a mild bleeding tendency $[78,93]$. Mild mucocutaneous bleeding symptoms have been reported for subjects with compound heterozygous mutations or a frame-shift mutation in the GP6 gene [94]. In addition, large scale genome-wide analyses indicate that variation in the GP6 locus is one of the major predictors in determining the extent of platelet activation $[95,96]$.
In vitro perfusions with mouse blood indicated that thrombus formation on collagen relies on the presence of both FcR $\gamma$-chain and GPVI $[97,98]$. Thrombus formation on collagen is greatly impaired in mice lacking proteins of the GPVI signalling complex, i.e. PLC $\gamma$ or PI3K isoforms [85,99], whereas animals with constitutively active PLC $\gamma 2$ show aggravated thrombus formation [100]. These mouse studies jointly suggest that the major functional role of GPVI is the limiting of excessive blood loss upon injury with substantial collagen exposure [101].

Since anti-GPVI agents have the potential to reduce arterial thrombus formation with limited effect on haemostatic activity, there have been several initiatives to develop such substances. Small GPVI-inhibiting $\mathrm{m}$ olecules (e.g., Losartan) and blocking anti-GPVI antibodies (10B12, 9012) have been generated for experimental use with animal and human blood $[88,93]$. Such anti-GPVI agents strongly inhibit thrombus formation on collagen under flow conditions [102,103]. Injection of the anti-GPVI

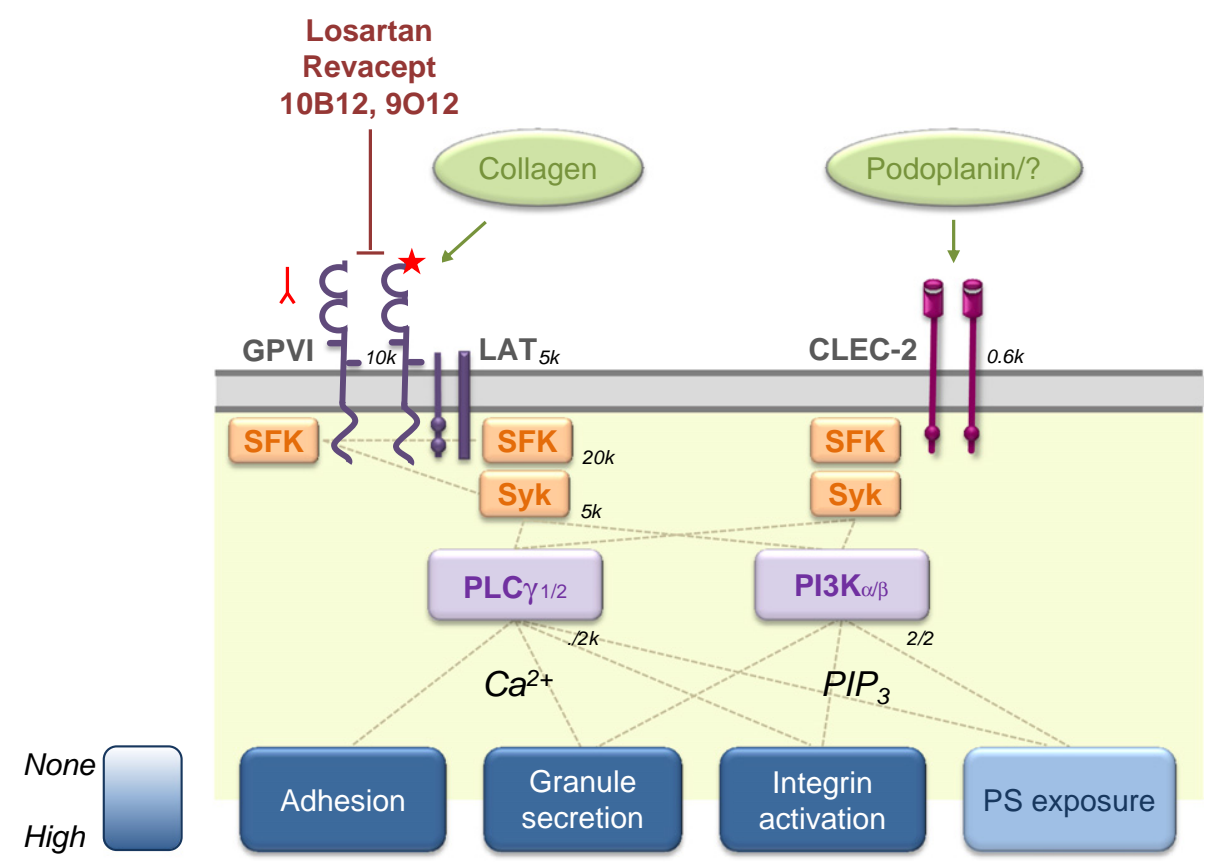

Fig. 6. Signalling and intervention via the collagen receptor, GPVI, and the platelet CLEC-2 receptor. For explanation, see Fig. 1; SFK, Src family kinases. 
OM2-Fab fragment into cynomolgus monkeys caused inhibition of collagen-induced platelet aggregation [104]. In a different approach, a soluble dimeric GPVI-Fc fusion protein (Revacept) has been generated to block the GPVI-binding sites on exposed collagen, causing suppression of murine arterial thrombosis [105]. This GPVI-Fc fusion protein is presently tested in a phase III trial [106]. Taken together, GPVI is an interesting therapeutic target that deserves further exploration.

\subsection{Novel receptor, CLEC-2}

The C-type lectin-like type II membrane glycoprotein CLEC-2 has recently been identified as a receptor that also can strongly activate platelets. Ligands of this receptor are the snake venom toxin, rhodocytin and the glycoprotein podoplanin [107,108]. The physiological ligand of CLEC-2 in the vascular system is still unclear. The signalling pathway evoked by CLEC-2 clustering is similar to that of GPVI, i.e. via activated protein tyrosine kinases resulting in PLC $\gamma$ activation, although in this case the mechanism does more rely on Syk than on Src kinases (Fig. 6) [101,107]. Phosphoproteomics analysis of activated platelets also points to a substantial, but not complete overlap of GPVI and CLEC-2 signalling events [109].

In mice, conditional knockout of CLEC-2 or treatment with antiCLEC-2 antibody caused reduced thrombus stability and prolonged tail bleeding times $[107,110]$. Strikingly, combined in vivo depletion of GPVI and CLEC-2 by antibody treatment, or genetic deficiency of platelet GPVI plus CLEC-2 resulted in severe impairment of arterial thrombus formation, but at the expense of prolonged bleeding times [111]. This points to functional redundancy of the two receptors in thrombosis and haemostasis. Although there are only few human data available, together this suggests that CLEC- 2 is an interesting therapeutic target, but bleeding might be an unavoidable side effect.

\subsection{Fibrinogen receptor, integrin $\alpha_{I I b} \beta_{3}$}

Integrin $\alpha_{\text {III }} \beta_{3}$ (GPIIb/IIIa) is the most abundantly expressed receptor on platelets. On resting platelets $\alpha_{\text {IIb }} \beta_{3}$ assumes a bent form with low ligand affinity. Upon platelet activation by most agonists, the integrin opens by a reversible conformational change, which increases its affinity for fibrinogen, fibronectin, vitronectin and VWF. This inside-out integrin signalling occurs via $\mathrm{Ca}^{2+}$-dependent activation of protein kinase $\mathrm{C}$ or CalDAG-GEFI, culminating in Rap1b activation and binding of the actin cytoskeletal proteins talin- 1 and kindlin- 3 to the cytoplasmic $\alpha_{\text {IIb }} \beta_{3}$ domains (Fig. 7A) [112-114]. In the activated state, $\alpha_{\text {IIb }} \beta_{3}$ supports platelet adhesion to fibrinogen and platelet aggregation. Ligand binding to $\alpha_{\mathrm{II}} \beta_{3}$ furthermore leads to a train of signalling events, mediated by Src and Syk protein tyrosine kinases, a process known as outside-in signalling (Fig. 7B) [115]. This process drives the spreading of platelets on fibrinogen, the retraction of fibrin clots, and the procoagulant activity of platelets [116].

Mutations in the genes encoding for $\alpha_{\text {IIb }}$ and $\beta_{3}$ give rise to one of the most common platelet disorders, Glanzmann's thrombasthenia. Glanzmann patients have platelets lacking $\alpha_{\mathrm{III}} \beta_{3}$ or with non-functional $\alpha_{\text {IIb }} \beta_{3}$, and characteristically show mucocutaneous and gastrointestinal bleeding symptoms as well as excessive trauma-related bleeding [117]. Platelets from these patients show impaired aggregation, spreading and clot retraction. Mice lacking expression of the $\alpha_{\text {IIb }}$ or $\beta_{3}$-chain are greatly impaired in arterial thrombosis, and have a bleeding phenotype, with prolonged tail bleeding times and spontaneous haemorrhages [118,119].

The autosomal recessive syndrome, leukocyte adhesion deficiency type III (LAD-III or LAD-1/variant), refers to a dysfunction of integrins $\beta_{1}, \beta_{2}$ and $\beta_{3}$ in platelets and leukocytes. While the integrin expression levels are normal, LAD-III patients experience severe bleeding and recurrent infections. Recently, it was established that this disorder is caused by mutations in the gene of kindlin-3, which result in abrogated integrin inside-out signalling [120,121]. The bleeding phenotype is explained particularly, but not exclusively, by the inability of $\alpha_{\mathrm{IIb}} \beta_{3}$ mediated platelet aggregation [7].

Three inhibitors of $\alpha_{\text {IIb }} \beta_{3}$ are available for clinical use, namely Abciximab, Eptifibatide and Tirofiban. These drugs are given intravenously to patients undergoing percutaneous coronary intervention
B

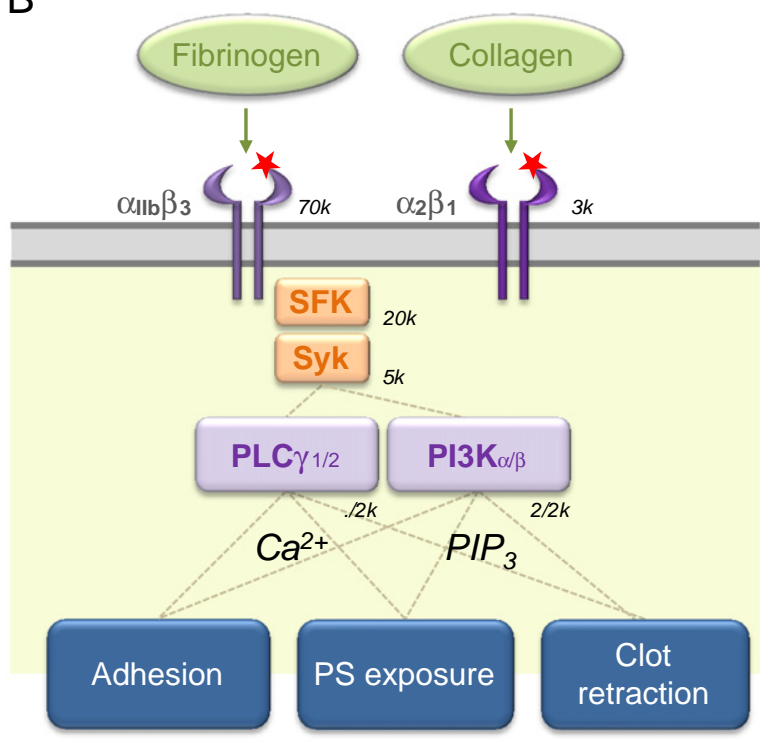

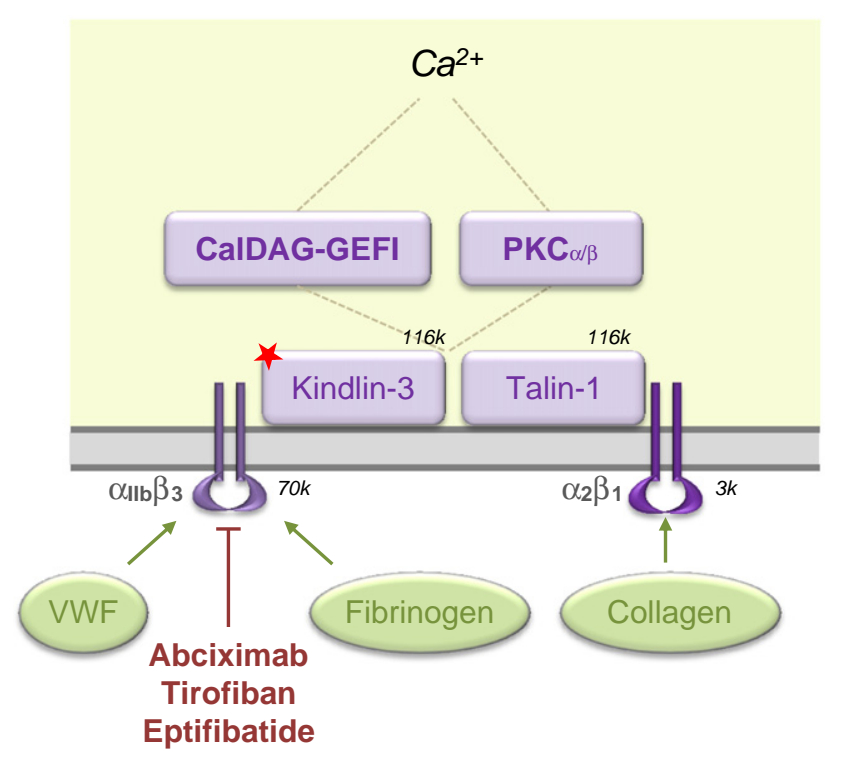

Fig. 7. Signalling and intervention via platelet integrins. (A) Inside-out signalling, (B) outside-in signalling. For explanation, see Fig. 1. 
after acute coronary syndrome. Integrin inhibitors have been reported to cause more haemorrhagic events in women, but this might be due to improper weight-adjusted dosing [122]. Cardiologists mostly use $\alpha_{\text {IIb }} \beta_{3}$ inhibitors in high-risk patients not pretreated with $\mathrm{P}_{2} \mathrm{Y}_{12}$ blockers [123]. In the past, also oral $\alpha_{\mathrm{IIb}} \beta_{3}$ inhibitors have been tested, but clinical trials were cancelled due to increased mortality, likely due to a ligand-mimetic function of the compounds, provoking fibrinogen binding to $\alpha_{\text {IIb }} \beta_{3}$ [124]. Summarizing, given the fundamental role of $\alpha_{\text {IIb }} \beta_{3}$ in haemostasis, inhibition of this glycoprotein need to be performed with great care.

\subsection{Other platelet integrins}

Platelets also express other integrins than $\alpha_{\mathrm{IIb}} \beta_{3}$, which serve as receptors for adhesive proteins. At least for integrin $\alpha_{2} \beta_{1}$, receptor function depends on conformational changes and leads to outside-in signalling events. Integrin $\alpha_{2} \beta_{1}$ (GPIa/Ila) serves as receptor for fibrillar collagens. Its activation depends on cytoskeleton-mediated kindlin-3 and talin-1 interactions (Fig. 7A) [114]. Likely, lack of activation of $\alpha_{2} \beta_{1}$ explains why LAD-III patients (with defective kindlin-3) suffer from a more severe bleeding tendency than Glanzmann patients (missing only $\alpha_{\mathrm{IIb}} \beta_{3}$ ) [125].

In mice, deficiency in $\alpha_{2} \beta_{1}$ results in limited impairment in arterial thrombus formation, which is detected as increased thrombus instability [126]. Mice lacking $\alpha_{2}$ or $\beta_{1}$ show unchanged tail bleeding times $[97,127]$. However, combined deficiency of GPVI and $\alpha_{2} \beta_{1}$ leads to a severe bleeding tendency, accompanying major defects in thrombus formation [128]. This suggests that $\alpha_{2} \beta_{1}$ plays a supportive rather than essential role in the interaction between platelets and collagen [114], although recent evidence indicates that $\beta_{1}$ integrins do contribute to platelet activation processes [129]. Two patients suffering from minor bleeding are described with reduced expression of $\alpha_{2} \beta_{1}$ and impaired platelet adhesion to collagen [130,131]. However, whether the bleeding is due to the altered glycoprotein expression is unclear [78]. In studies of thrombus formation with mouse and human blood, $\alpha_{2} \beta_{1}$ enforces the GPVI-dependent platelet adhesion to collagen and ensuing platelet activation [62]. Taken together, $\alpha_{2} \beta_{1}$ seems to have a dispensable but still relevant role in haemostasis and thrombosis.

Recently, also the platelet receptor for vascular laminins, integrin $\alpha_{6} \beta_{1}$, was found to play an important role in murine platelet activation and arterial thrombosis in vivo [132], suggesting that also this integrin could be a target of antithrombotic treatment.

\section{Thrombus formation - interactions of multiple platelet receptors}

Flow studies have gained considerable insight into the combinatory roles of various platelet ligands and receptors in the process of thrombus formation, reflecting those in haemostasis and arterial thrombosis. Current models of thrombus formation start with sheardependent platelet adhesion to VWF via GPIb-V-IX followed by platelet activation via collagen, but also other platelet substrates will contribute to initial platelet adhesion [133]. Platelet activation via GPVI, and likely also CLEC-2, initiates responses like shape change (pseudopod formation), $\alpha / \delta$-granule secretion, thromboxane release and integrin activation which, together, evoke a train of autocrine stimulatory events to activate and trap flowing platelets into the growing thrombus $[61,82]$. Thrombus formation is thus seen as a multifactorial event with amplification loops by receptor interactions of thrombin/PAR isoforms, ADP/P2Y isoforms, ATP $/ \mathrm{P}_{2} \mathrm{X}_{1}$, thromboxane/TP receptors and fibrinogen $/ \alpha_{\mathrm{IIb}} \beta_{3}$ (Fig. 8). However, also many other ligand-receptor interactions - not discussed in this review - contribute to this complexity. These involve, for instance, contact-dependent signalling processes, activation via $\alpha$-granule secretion products (Gas6, thrombospondin), tyrosine phosphatase-linked receptors, and mechanisms controlling fibrin formation, thrombus contraction and thrombus stability [134-136]. Moreover, these processes may occur at different loci in a growing thrombus. Below, we discuss platelet activation processes that are most relevant for haemostasis in man.

The combined involvement of multiple ligand-receptor combinations in thrombus formation becomes especially apparent, when more than one interaction is absent. This is the case for patients lacking $\alpha$ - or $\delta$ granules in platelets, often associated with bleeding symptoms of various severities. Patients with the rare Hermansky-Pudlak syndrome have mutations in one of nine HPS genes, resulting in complete $\delta$-granule and lysosome deficiency $[7,137]$. The functional defect of platelets is at least in part explained by impaired ADP and ATP secretion. More common is a partial impairment of $\delta$-granule secretion with unknown genetic causes [137]. Abnormalities in the $\alpha$-granules, which store a large variety of proteins, are seen in several syndromes. Well studied is the Gray platelet syndrome, a mild bleeding disorder characterized by absence of $\alpha$-granules and accompanied with thrombocytopenia, due to mutations in the NBEAL2 gene [7,137]. Mice deficient in Nbeal2 phenocopy this syndrome and are protected from arterial thrombus formation; their platelets show diminished adhesion, aggregation and procoagulant activity [138]. It is still unclear which of the $\alpha$-granule stored proteins mediate these platelet responses. Platelet cytoskeleton defects, such as May-Hegglin anomaly (MYH9 gene mutation) and Wiskott-Aldrich syndrome (WAS mutation) are accompanied by changes in platelet size and thrombocytopenia [7]. Pharmacological interventions to inhibit platelet granule secretion or cytoskeletal changes are not known.

A few intracellular signalling proteins with major roles in platelet functions have been studied as potential targets for therapy. Well advanced are studies on pharmacological inhibition of PI3K, particularly of the $\beta$ isoform. In flow perfusion studies, PI3K $\alpha / \beta$ blockers suppress collagen-induced $\mathrm{Ca}^{2+}$ mobilization, secretion, integrin activation and platelet procoagulant activity [85]. A phase I study consisting of intravenous infusion of the PI3K $\beta$ blocker AZD6482 (an analogue of TGX-221) indicated a strong platelet-inhibiting effect ex vivo [139].

\section{Bleeding and platelet dysfunction or inhibition}

\subsection{Predicting mild platelet disorders with questionnaires}

Typical bleeding symptoms that accompany quantitative or qualitative platelet disorders are excessive bruising, prolonged menses and abnormal bleeding after haemostatic challenges. The magnitude of bleeding depends on the type and severity of the platelet defect [1]. Since patients with a platelet disorder often display only mild bleeding symptoms, which are also features of von Willebrand disease or coagulation deficiencies, proper diagnosis is not always easy [140]. The complexity is well illustrated by the outcome of the UK GAPP study where, in subjects with suspected platelet function deficiencies and abnormal bleeding symptoms, the genetic causes of the signalling defects could only be determined in a minority of the subjects [18].

In the clinic, there is ongoing interest in the development of bleeding assessment tools (BATs) for the diagnostic evaluation of haemorrhagic symptoms by way of a questionnaire and bleeding score. Most questions concern the family history of spontaneous and challenged bleeding events, as well as the frequency and severity of the bleeding symptoms. Specific BATs have been developed for von Willebrand disease, paediatric patients, and women with menorrhagia [141]. In 2010 the ISTH published a consensus BAT to standardize the description of significant bleeding symptoms and the diagnosis of bleeding disorders with main focus on von Willebrand disease [142]. While useful for the documentation of all relevant bleeding symptoms in the prospective GAPP study, the ISTH-BAT score was not predictive for platelet function deficiencies, based on lumi-aggregometry measurements [143]. It should be noted though, that a laboratory defect not always needs to be accompanied by a bleeding phenotype. Since the ISTH-BAT documents on recurrent and mild haemorrhages, which are characteristic for platelet function disorders, further refinement of this BAT may aid in the diagnosis of mild platelet defects. 


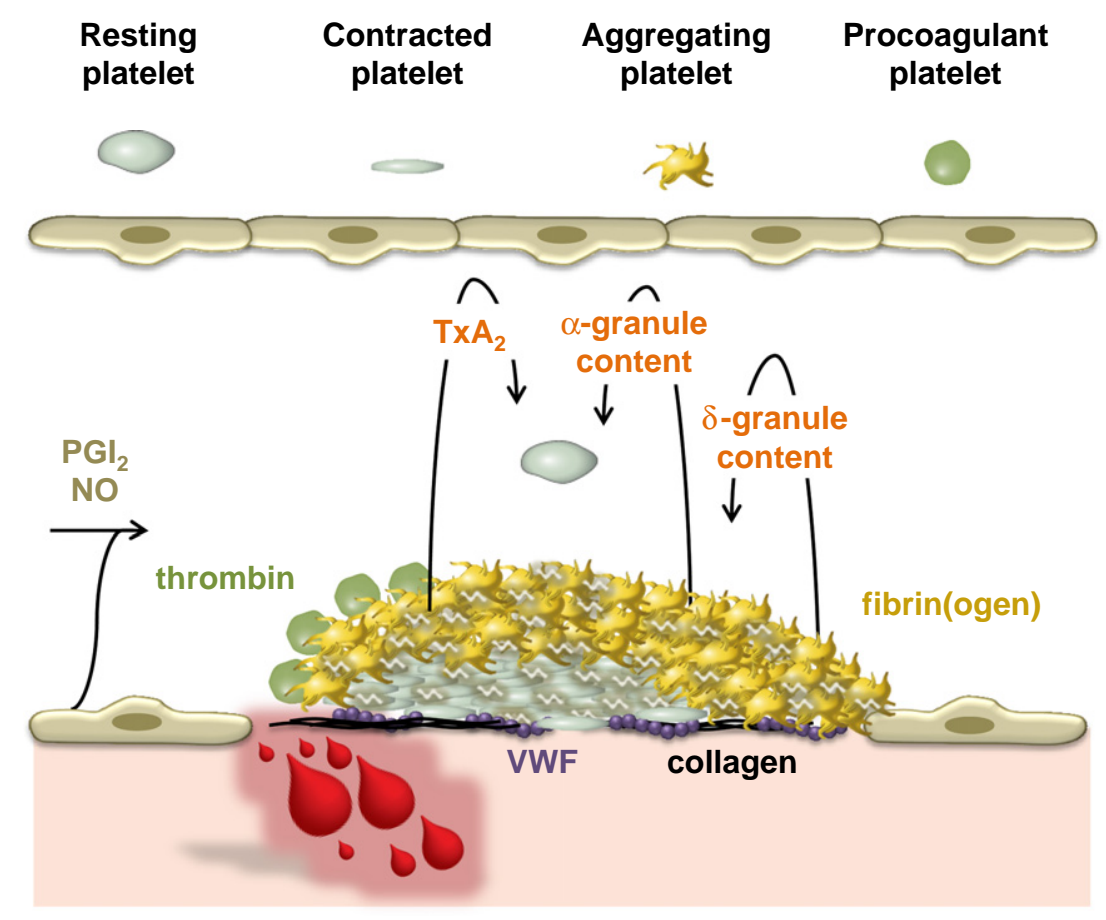

Fig. 8. Simplified mechanism of platelet agonists and adhesive ligands in thrombus formation. See text.

For inherited platelet disorders bleeding symptoms are usually experienced lifelong, so that retrospective evaluation of the bleeding episodes is of particular importance. On the other hand, sudden (acquired) bleeding due to the use of antiplatelet medication requires description of the acute symptoms [142]. Detailed registration of bleeding events by physicians is important not only for prediction, but also for safety reasons. Bleeding events related to the use of antiplatelet therapy, whether or not in combination with invasive procedures, are systematically reported, although this occurs not always according to the same bleeding definitions. Records are made of events during clinical trials and after the prescription of approved drugs (particularly Aspirin and $\mathrm{P}_{2} \mathrm{Y}_{12}$ inhibitors). Informative BATs to evaluate such acquired bleeding tendencies have not yet been published. At present, listed are only clinically relevant bleedings, requiring transfusion of red blood cells and/or serious adverse events (e.g. intracranial haemorrhages). In an attempt to accomplish uniformity in bleeding definitions for cardiovascular clinical trials, a consensus classification was published allowing safety comparisons between studies, which deserves proper attention [144].

\subsection{Laboratory testing of platelet dysfunction}

Particularly in the last years, efforts have been made to standardize laboratory methods for platelet function testing. Quantitative platelet disorders can be detected by measuring platelet count and mean platelet volume in blood samples. Platelet aggregation in platelet-rich plasma in response to a panel of agonists, determined by light transmission aggregometry (LTA), is the current golden standard for detecting functional abnormalities [1]. Since LTA is relatively insensitive in identifying defects in $\delta$-granule secretion, platelet release of ATP needs to be determined additionally, e.g. by lumi-aggregometry. Recommendations have recently been published for the use of standardized LTA tests for UK laboratories [145] and the ISTH [146]. A streamlined, validated panel of platelet agonists (ADP, adrenaline, arachidonic acid, collagen, TRAP, ristocetin) has been developed for diagnosing heritable platelet function disorders by testing with LTA and ATP secretion [18].

Replacing the early method of whole blood impedance aggregometry, the Multiplate and VerifyNow devices are increasingly used for determining platelet aggregation in whole blood, but still require more clinical validation. The PFA-100 is particularly used for testing sheardependent platelet aggregation in response to collagen/ADP or collagen/ adrenaline. The test is capable of detecting severe platelet function defects (Bernard-Soulier, Glanzmann's thrombasthenia) and most types of von Willebrand disease [147]. However, its sensitivity for less severe defects, like $\delta$-granule storage pool deficiencies, is low [148].

Flow cytometry is frequently used for specific platelet function testing or for conditions where platelet counts are too low for LTA [149]. Flow cytometry allows the quantification of platelet receptors, the detection of platelet surface activation markers, and of platelet procoagulant activity. Hence, agonist-induced integrin activation, secretion of $\alpha$ - and $\delta$-granules, and phosphatidylserine expression can easily be determined. This technique has already been used as a readout to determine the genetic determinants of platelet signalling pathways [95]. Flow cytometric tests for assessing (agonist-induced) platelet function in whole blood are in the experimental phase [150,151].

Since platelet activation and coagulation are interdependent processes [3], platelet function - in particular procoagulant activity - can also be tested in platelet-rich plasma by way of thrombin generation assays $[4,152]$. Recommendations for standardized measurement of platelet-dependent thrombin generation have recently been published by the ISTH [153]. Developments of a CAT-based assay in whole blood can improve clinical applicability of this type of tests [154]. However, their predictive value for platelet-related bleeding still needs to be established. Flow chambers have been used to measure thrombus formation in combination with coagulation (fibrin) at defined shear stress conditions [155]. Efforts are undertaken for better standardization of these flow-based assays and adaption to smaller volumes of blood [156,157].

\subsection{Laboratory testing of platelet inhibition}

For optimal patient care it is considered to be important to assess the effectiveness of antiplatelet therapy. This is predominantly an issue in cases of dual antiplatelet therapy with Aspirin and $\mathrm{P}_{2} \mathrm{Y}_{12}$ receptor blockers, as is the standard therapy for patients with acute coronary syndrome or undergoing percutaneous coronary intervention. Due to heterogeneity in individual responses to especially Clopidogrel treatment, 
inhibition of platelet function is suboptimal in a considerable part of the treated patients. This so-called high on-treatment platelet reactivity (HPR) associates with an increased risk of secondary atherothrombotic events [42,158]. In this context, also the reported variability in responsiveness to Aspirin requires attention [159]. Platelet function testing in relation to bleeding is also important in patients using the new, potent $\mathrm{P} \mathrm{Y}_{12}$ blockers, Prasugrel and Ticagrelor, where low on-treatment platelet reactivity (LPR) is a matter of concern [160]. Together, this would advocate for monitoring platelet reactivity under treatment and concomitant individualized dosing of $\mathrm{P}_{2} \mathrm{Y}_{12}$ blockers.

A platelet function-tailored approach with Clopidogrel may be most effective for patients with a high risk of stent thrombosis [159]. Further studies, especially with the new $\mathrm{P}_{2} \mathrm{Y}_{12}$ blockers, are required to support the rationale for personalized treatment [158]. First efforts have been made for defining a therapeutic window for on-treatment platelet reactivity upon intake of $\mathrm{P}_{2} \mathrm{Y}_{12}$ blockers to minimalize both ischemic and bleeding events [160]. Several platelet function assays are currently available for testing the efficacy and safety of antiplatelet therapy. Although LTA is still the golden standard, currently available point-ofcare tests are more convenient for use in daily clinical practice. Of these, the VerifyNow and Multiplate tests may reflect most accurately the variable responsiveness to Aspirin and $\mathrm{P}_{2} \mathrm{Y}_{12}$ blockers, while the predictive value of the PFA-100 test for $\mathrm{P}_{2} \mathrm{Y}_{12}$ inhibition is limited [161].

\section{Concluding remarks}

Recent research on platelet responses in whole blood flow studies and experimental thrombosis studies has greatly contributed to our insight into main platelet receptors in thrombosis and haemostasis. In man, haemorrhagic complications can be caused by defective platelet receptors or by therapeutic inhibition of these receptors. It would be important to register these bleeding events in similar ways by using uniform assessment tools and function tests.

\section{Practice points}

- Study of thrombus formation, in whole blood flow studies and experimental murine thrombosis studies, is of relevance to understand the platelet responses in thrombosis and haemostasis in man.

- Main platelet receptors with established or potential clinical relevance are those of thrombin, thromboxane $A_{2}, A D P$, ATP prostaglandins, von Willebrand factor, collagen, CLEC2 ligand, fibrinogen and laminin.

- Platelet dysfunction, either inherited or acquired due to medication, may lead to bleeding, but bleeding symptoms are assessed in different ways.

\section{Research agenda}

- Establishment of the therapeutic window for (potential) antiplatelet agents for optimal efficacy in preventing thrombosis with minimal bleeding.

- Development of bleeding assessment tools for identifying platelet function disorders or low on-treatment platelet reactivity; comparison of these tools to outcome of platelet function tests.

\section{Conflicts of interest}

The authors have obtained research grants from AstraZeneca.

\section{Acknowledgements}

We apologize to those authors who provided important contributions to this broad research field, but whose work could not be cited due to space restrictions. This work was supported by grants from the Dutch Landsteiner Foundation for Blood Transfusion Research (1006) and the Centre for Translational Molecular Medicine (INCOAG).

\section{References}

[1] Hayward CP. Diagnostic evaluation of platelet function disorders. Blood Rev 2011;25:169-73.

[2] Mackman N. Triggers, targets and treatments of thrombosis. Nature 2008;451:914-8.

[3] Heemskerk JW, Mattheij NJ, Cosemans JM. Platelet-based coagulation: different populations, different functions. J Thromb Haemost 2013;11:2-16.

[4] Hemker HC, Al Dieri R, Béguin S. Thrombin generation assays: accruing clinical relevance. Curr Opin Hematol 2005;11:170-5.

[5] Coughlin SR. Protease-activated receptors in hemostasis, thrombosis and vascular biology. J Thromb Haemost 2005;3:1800-14.

[6] Kim S, Foster C, Lecchi A, Quinton TM, Prosser DM, Jin J, et al. Protease-activated receptors 1 and 4 do not stimulate Gi signaling pathways in the absence of secreted ADP and cause human platelet aggregation independently of Gi signaling. Blood 2002;99:3629-36.

[7] Nurden A, Nurden P. Advances in our understanding of the molecular basis of disorders of platelet function. J Thromb Haemost 2011;9(Suppl. 1):76-91.

[8] Weiss EJ, Hamilton JR, Lease KE, Coughlin SR. Protection against thrombosis in mice lacking PAR3. Blood 2002; 100:3240-4.

[9] Hamilton JR, Cornelissen I, Coughlin SR. Impaired hemostasis and protection against thrombosis in protease-activated receptor 4-deficient mice is due to lack of thrombin signaling in platelets. J Thromb Haemost 2004;2:1429-35.

[10] Vandendries ER, Hamilton JR, Coughlin SR, Furie B, Furie BC. Par4 is required for platelet thrombus propagation but not fibrin generation in a mouse model of thrombosis. Proc Natl Acad Sci U S A 2007;104:288-92.

[11] Tricoci P, Huang Z, Held C, Moliterno DJ, Armstrong PW, Van de Werf F, et al Thrombin-receptor antagonist vorapaxar in acute coronary syndromes. N Engl J Med 2012;366:20-33.

[12] Morrow DA, Braunwald E, Bonaca MP, Ameriso SF, Dalby AJ, Fish MP, et al. Vorapaxar in the secondary prevention of atherothrombotic events. N Engl J Med 2012;366:1404-13.

[13] Scirica BM, Bonaca MP, Braunwald E, De Ferrari GM, Isaza D, Lewis BS, et al Vorapaxar for secondary prevention of thrombotic events for patients with previous myocardial infarction: a prespecified subgroup analysis of the TRA 2 degrees P-TIMI 50 trial. Lancet 2012;380:1317-24.

[14] O'Donoghue ML, Bhatt DL, Wiviott SD, Goodman SG, Fitzgerald DJ, Angiolillo DJ, et al. Safety and tolerability of atopaxar in the treatment of patients with acute coronary syndromes: the lessons from antagonizing the cellular effects of thrombinacute coronary syndromes trial. Circulation 2011;123:1843-53.

[15] Van de Werf F. Inhibitors of the platelet thrombin receptor: will they live up to their promises? Circulation 2011;123:1833-5.

[16] Li Z, Zhang G, Le Breton GC, Gao X, Malik AB, Du X. Two waves of platelet secretion induced by thromboxane $A_{2}$ receptor and a critical role for phosphoinositide 3-kinases. J Biol Chem 2003;278:30725-31.

[17] Offermanns S. Activation of platelet function through G protein-coupled receptors. Circ Res 2006;99:1293-304.

[18] Dawood BB, Lowe GC, Lordkipanidze M, Bem D, Daly ME, Makris M, et al. Evaluation of participants with suspected heritable platelet function disorders including recommendation and validation of a streamlined agonist panel. Blood 2012;120:5041-9.

[19] Thomas DW, Mannon RB, Mannon PJ, Latour A, Oliver JA, Hoffman M, et al. Coagulation defects and altered hemodynamic responses in mice lacking receptors for thromboxane A2. J Clin Invest 1998;102:1994-2001.

[20] Lewis HD, Davis JW, Archibald DG, Steinke WE, Smitherman TC, Doherty JE, et al Protective effects of aspirin against acute myocardial infarction and death in men with unstable angina. Results of a Veterans Administration Cooperative Study. N Engl J Med 1983;309:396-403.

[21] Cairns JA, Gent M, Singer J, Finnie KJ, Froggatt GM, Holder DA, et al. Aspirin, sulfinpyrazone, or both in unstable angina. Results of a Canadian multicenter trial. N Engl J Med 1985;313:1369-75.

[22] Awtry EH, Loscalzo J. Aspirin. Circulation 2000;101:1206-18.

[23] Floyd CN, Ferro A. Mechanisms of aspirin resistance. Pharmacol Ther 2014;141:69-78.

[24] Olsen AM, Gislason GH, Fosbol EL. Time-perspective in cardiovascular risk of NSAID use after first-time myocardial infarction. Curr Opin Cardiol 2013;28:683-8.

[25] Fiessinger JN, Bounameaux H, Cairols MA, Clement DL, Coccheri S, Fletcher JP, et al. Thromboxane antagonism with terutroban in peripheral arterial disease: the TAIPAD study. J Thromb Haemost 2010;8:2369-76.

[26] Lesault PF, Boyer L, Pelle G, Covali-Noroc A, Rideau D, Akakpo S, et al. Daily administration of the TP receptor antagonist terutroban improved endothelial function in highcardiovascular-risk patients with atherosclerosis. Br J Clin Pharmacol 2011;71:844-51. 
[27] Gachet C. P2 receptors, platelet function and pharmacological implications. Thromb Haemost 2008;99:466-72.

[28] Leon C, Hechler B, Freund M, Eckly A, Vial C, Ohlmann P, et al. Defective platelet aggregation and increased resistance to thrombosis in purinergic $\mathrm{P}_{2} \mathrm{Y}_{1}$ receptor-null mice. J Clin Invest 1999;104:1731-7.

[29] Cattaneo $\mathrm{M}$. The platelet $\mathrm{P}_{2} \mathrm{Y}_{12}$ receptor for adenosine diphosphate: congenital and drug-induced defects. Blood 2011;117:2102-12.

[30] Schoenwaelder SM, Ono A, Sturgeon S, Chan M, Mangin P, Maxwell MJ, et al. Identification of a unique co-operative PI 3-kinase signaling mechanism regulating integrin $\alpha$ IIbß33 adhesive function in platelets. J Biol Chem 2007;282:28648-58.

[31] Garcia A, Kim S, Bhavaraju K, Schoenwaelder SM, Kunapuli SP. Role of phosphoinositide 3-kinase $\beta$ in platelet aggregation and thromboxane $A_{2}$ generation mediated by Gi signalling pathways. Biochem J 2010;429:369-77.

[32] Cosemans JM, Munnix IC, Wetzker R, Heller R, Jackson SP, Heemskerk JW. Continuous signaling via PI3K isoforms beta and gamma is required for platelet ADP receptor function in dynamic thrombus stabilization. Blood 2006;108:3045-52.

[33] Fabre JE, Nguyen M, Latour A, Keifer JA, Audoly LP, Coffman TM, et al. Decreased platelet aggregation, increased bleeding time and resistance to thromboembolism in P2Y ${ }_{1}$-deficient mice. Nat Med 1999;5:1199-202.

[34] Hechler B, Zhang Y, Eckly A, Cazenave JP, Gachet C, Ravid K. Lineage-specific overexpression of the $\mathrm{P}_{2} \mathrm{Y}_{1}$ receptor induces platelet hyper-reactivity in transgenic mice. J Thromb Haemost 2003;1:155-63.

[35] Hollopeter G, Jantzen HM, Vincent D, Li G, England L, Ramakrishnan V, et al. Identification of the platelet ADP receptor targeted by antithrombotic drugs. Nature 2001;409:202-7.

[36] Watson S, Daly M, Dawood B, Gissen P, Makris M, Mundell S, et al. Phenotypic approaches to gene mapping in platelet function disorders: identification of new variant of P2Y $12, \mathrm{TxA}_{2}$ and GPVI receptors. Hämostaseologie 2010;30:29-38.

[37] André P, Delaney SM, LaRocca T, Vincent D, DeGuzman F, Jurek M, et al. P2Y 12 regulates platelet adhesion/activation, thrombus growth, and thrombus stability in injured arteries. J Clin Invest 2003;112:398-406

[38] Zhang Y, Ye J, Hu L, Zhang S, Zhang SH, Li Y, et al. Increased platelet activation and thrombosis in transgenic mice expressing constitutively active $\mathrm{P}_{2} \mathrm{Y}_{12}$. J Thromb Haemost 2012;10:2149-57.

[39] Snoep JD, Hovens MM, Eikenboom JC, van der Bom JG, Jukema JW, Huisman MV. Clopidogrel nonresponsiveness in patients undergoing percutaneous coronary intervention with stenting: a systematic review and meta-analysis. Am Heart J 2007; 154:221-31.

[40] Gorgi MA, Cohen-Arazi H, Gonzalez CD, Di Girolamo G. Beyond efficacy: pharmacokinetic differences between clopidogrel, prasugrel and ticagrelor. Expert Opin Pharmacother 2011;12:1285-95.

[41] Roberts JD, Wells GA, Le May MR, Labinaz M, Glover C, Froeschl M, et al. Point-ofcare genetic testing for personalisation of antiplatelet treatment (RAPID GENE): a prospective, randomised, proof-of-concept trial. Lancet 2012;379:1705-11.

[42] Wallentin L, Varenhorst C, James S, Erlinge D, Braun OO, Jakubowski JA, et al. Prasugrel achieves greater and faster $\mathrm{P}_{2} \mathrm{Y}_{12}$ receptor-mediated platelet inhibition than clopidogrel due to more efficient generation of its active metabolite in aspirin-treated patients with coronary artery disease. Eur Heart J 2008;29:21-30.

[43] Pandit A, Aryal MR, Pandit AA, Jalota L, Hakim FA, Mookadam F, et al. Cangrelor versus clopidogrel in percutaneous coronary intervention: a systematic review and meta-analysis. EuroIntervention 2013 [in press].

[44] Fung CYE, Cendana C, Farndale RW, Mahaut-Smith MP. Primary and secondary agonists can use $\mathrm{P}_{2} \mathrm{X}_{1}$ receptors as a major pathway to increase intracellular $\mathrm{Ca}^{2+}$ in the human platelet. J Thromb Haemost 2007;5:910-7.

[45] Oury C, Toth-Zsamboki E, Van Geet C, Thys C, Wei L, Nilius B, et al. A natural dominant negative $\mathrm{P}_{2} \mathrm{X}_{1}$ receptor due to deletion of a single amino acid residue. J Biol Chem 2000;275:22611-4.

[46] Mulryan K, Gitterman DP, Lewis CJ, Vial C, Leckie BJ, Cobb AL, et al. Reduced vas deferens contraction and male infertility in mice lacking $\mathrm{P} 2 \mathrm{X}_{1}$ receptors. Nature 2000;403:86-9.

[47] Hechler B, Lenain N, Marchese P, Vial C, Heim V, Freund M, et al. A role of the fast ATP-gated P2X $\mathrm{X}_{1}$ cation channel in thrombosis of small arteries in vivo. J Exp Med 2003;198:661-7.

[48] Mustard JF, Kinlough-Rathbone RL, Packham MA. Prostaglandins and platelets. Annu Rev Med 1980;31:89-96

[49] Gegenbauer K, Elia G, Blanco-Fernandez A, Smolenski A. Regulator of G-protein signaling 18 integrates activating and inhibiting signaling in platelets. Blood 2012;119:3799-807.

[50] Subramanian H, Zahedi RP, Sickmann A, Walter U, Gambaryan S. Phosphorylation of CalDAG-GEFI by protein kinase A prevents Rap1b activation. J Thromb Haemost 2013;11:1574-82.

[51] Murata T, Ushikubi F, Matsuoka T, Hirata M, Yamasaki A, Sugimoto Y, et al. Altered pain perception and inflammatory response in mice lacking prostacyclin receptor. Nature 1997:388:678-82.

[52] Stitham J, Arehart E, Elderon L, Gleim SR, Douville K, Kasza Z, et al. Comprehensive biochemical analysis of rare prostacyclin receptor variants: study of association of signaling with coronary artery obstruction. J Biol Chem 2011;286:7060-9.

[53] Petrucci G, De Cristofaro R, Rutella S, Ranelletti FO, Pocaterra D, Lancellotti S, et al. Prostaglandin E2 differentially modulates human platelet function through the prostanoid EP2 and EP3 receptors. J Pharmacol Exp Ther 2011;336:391-402.

[54] Iyu D, Glenn JR, White AE, Johnson AJ, Fox SC, Heptinstall S. The role of prostanoid receptors in mediating the effects of $\mathrm{PGE}_{2}$ on human platelet function. Platelets 2010;21:329-42.

[55] Philipose S, Konya V, Sreckovic I, Marsche G, Lippe IT, Peskar BA, et al. The prostaglandin E2 receptor EP4 is expressed by human platelets and potently inhibits platelet aggregation and thrombus formation. Arterioscler Thromb Vasc Biol 2010;30:2416-23.

[56] Heptinstall S, Espinosa DI, Manolopoulos P, Glenn JR, White AE, Johnson A, et al. DG-041 inhibits the EP3 prostanoid receptor: a new target for inhibition of platelet function in atherothrombotic disease. Platelets 2008;19:605-13.

[57] Singh J, Zeller W, Zhou N, Hategen G, Mishra R, Polozov A, et al. Antagonists of the EP3 receptor for prostaglandin $E_{2}$ are novel antiplatelet agents that do not prolong bleeding. ACS Chem Biol 2009;4:115-26.

[58] Fox SC, May JA, Johnson A, Hermann D, Strieter D, Hartman D, et al. Effects on platelet function of an EP3 receptor antagonist used alone and in combination with a P2Y 12 antagonist both in-vitro and ex-vivo in human volunteers. Platelets 2013;24:392-400.

[59] De Ceunynck K, De Meyer SF, Vanhoorelbeke K. Unwinding the von Willebrand factor strings puzzle. Blood 2013;121:270-7.

[60] Yago T, Lou J, Wu T, Yang J, Miner JJ, Coburn L, et al. Platelet glycoprotein Ibalpha forms catch bonds with human WT vWF but not with type 2B von Willebrand disease vWF. J Clin Invest 2008;118:3195-207.

[61] Ruggeri ZM. The role of von Willebrand factor in thrombus formation. Thromb Res 2007;120:S5-9.

[62] Auger JM, Kuijpers MJ, Senis YA, Watson SP, Heemskerk JW. Adhesion of human and mouse platelets to collagen under shear: a unifying model. FASEB J 2005;19:825-7.

[63] Nesbitt WS, Westein E, Tovar-Lopez FJ, Tolouei E, Mitchell A, Fu J, et al. A shear gradient-dependent platelet aggregation mechanism drives thrombus formation. Nat Med 2009;15:665-73.

[64] Westein E, van der Meer AD, Kuijpers MJ, Frimat JP, van den Berg A, Heemskerk JW. Atherosclerotic geometries spatially confine and exacerbate pathological thrombus formation poststenosis in a von Willebrand factor-dependent manner. Proc Natl Acad Sci U S A 2013;110:1357-62.

[65] Kasirer-Friede A, Cozzi MR, Mazzucato M, De Marco L, Ruggeri ZM, Shattil SJ. Signaling through GPIb/V/IX activates $\alpha$ IIb $\beta 3$ independently of other receptors. Blood 2004;103:3403-11.

[66] Du X. Signaling and regulation of the platelet glycoprotein Ib-V-IX complex. Curr Opin Hematol 2007;14:262-9.

[67] Canobbio I, Bertoni A, Lova P, Paganini S, Hirsch E, Sinigaglia F, et al. Platelet activation by von Willebrand factor requires coordinated signaling through thromboxane $A_{2}$ and FcyIIA receptor. J Biol Chem 2001;276:26022-9.

[68] De Candia E, Hall SW, Rutella S, Landolfi R, Andrews RK, De Cristofaro R. Binding of thrombin to glycoprotein Ib accelerates the hydrolysis of PAR1 on intact platelets. J Biol Chem 2001;276:4692-8

[69] Cosemans JM, Schols SE, Stefanini L, de Witt S, Feijge MA, Hamulyak K, et al. Key role of glycoprotein $\mathrm{Ib} / \mathrm{V} / \mathrm{IX}$ and von Willebrand factor in platelet activationdependent fibrin formation at low shear flow. Blood 2011;117:651-60.

[70] Bergmeier W, Chauhan AK, Wagner DD. Glycoprotein Ib $\alpha$ and von Willebrand factor in primary platelet adhesion and thrombus formation: lessons from mice. Thromb Haemost 2008;99:264-70.

[71] Lenting PJ, Casari C, Christohpe OD, Denis CV. Von Willebrand factor: the old, the new and the unknown. J Thromb Haemost 2012;10:2428-37.

[72] Ware J, Russell S, Ruggeri ZM. Generation and rescue of a murine model of platelet dysfunction: the Bernard-Soulier syndrome. Proc Natl Acad Sci U S A 2000;97:2803-8.

[73] Kato K, Martinez C, Russell S, Nurden P, Nurden A, Fiering S, et al. Genetic deletion of mouse platelet glycoprotein Ib $\beta$ produces a Bernard-Soulier phenotype with increased $\alpha$-granule size. Blood 2004;104:2339-44.

[74] Ramakrishnan V, DeGuzman F, Bao M, Hall SW, Leung LL, Phillips DR. A thrombin receptor function for platelet glycoprotein Ib/IX unmasked by cleavage of glycoprotein V. Proc Natl Acad Sci U S A 2001:98:1823-8.

[75] Fontayne A, Meiring M, Lamprecht S, Roodt J, Demarsin E, Barbeaux P, et al. The humanized anti-glycoprotein Ib monoclonal antibody h6B4-Fab is a potent and safe antithrombotic in a high shear arterial thrombosis model in baboons. Thromb Haemost 2008;100:670-7.

[76] Wu D, Meiring M, Kotze HF, Deckmyn H, Cauwenberghs N. Inhibition of platelet glycoprotein Ib, glycoprotein IIb/IIIa, or both by monoclonal antibodies prevents arterial thrombosis in baboons. Arterioscler Thromb Vasc Biol 2002;22:323-8.

[77] Lillicrap D. Von Willebrand disease: phenotype versus genotype, deficiency versus disease. Thromb Res 2007;120:S11-6.

[78] Nieswandt B, Watson SP. Platelet-collagen interaction: is GPVI the central receptor? Blood 2003;102:449-61.

[79] Jung SM, Moroi M, Soejima K, Nakagaki T, Miura Y, Berndt MC, et al. Constitutive dimerization of glycoprotein VI (GPVI) in resting platelets is essential for binding to collagen and activation in flowing blood. J Biol Chem 2012;287:30000-13.

[80] Munnix IC, Kuijpers MJ, Auger J, Thomassen CM, Panizzi P, van Zandvoort MA, et al. Segregation of platelet aggregatory and procoagulant microdomains in thrombus formation: regulation by transient integrin activation. Arterioscler Thromb Vasc Biol 2007;27:2484-90.

[81] Watson SP, Auger JM, McCarty OJ, Pearce AC. GPVI and integrin $\alpha$ IIbß33 signaling in platelets. J Thromb Haemost 2005;3:1752-62.

[82] Stegner D, Nieswandt B. Platelet receptor signaling in thrombus formation. J Mol Med 2011;89:109-21.

[83] Senis YA. Protein-tyrosine phosphatases: a new frontier in platelet signal transduction. J Thromb Haemost 2013;11:1800-13.

[84] Tomlinson MG, Calaminus SD, Berlanga O, Auger JM, Bori-Sanz T, Meyaard L, et al. Collagen promotes sustained glycoprotein VI signaling in platelets and cell lines. J Thromb Haemost 2007:5:2274-83.

[85] Gilio K, Munnix IC, Mangin P, Cosemans JM, Feijge MA, van der Meijden PE, et al. Non-redundant roles of phosphoinositide 3-kinase isoforms alpha and beta in glycoprotein VI-induced platelet signaling and thrombus formation. J Biol Chem 2009:284:33750-62. 
[86] Stefanini L, Roden RC, Bergmeier W. CalDAG-GEFI is at the nexus of calciumdependent platelet activation. Blood 2009;114:2506-14.

[87] Heemskerk JW, Harper MT, Cosemans JM, Poole AW. Unravelling the different functions of protein kinase $C$ isoforms in platelets. FEBS Lett 2011;585:1711-6.

[88] Dütting S, Bender M, Nieswandt B. Platelet GPVI: a target for antithrombotic therapy. Trends Pharmacol Sci 2012;33:583-90.

[89] Schulte V, Rabie T, Prostredna M, Aktas B, Grüner S, Nieswandt B. Targeting of the collagen-binding site on glycoprotein $\mathrm{VI}$ is not essential for in vivo depletion of the receptor. Blood 2003;101:3948-52.

[90] Kuijpers MJE, Gilio K, Reitsma S, Nergiz-Unal R, Prinzen L, Heeneman S, et al. Complementary roles of platelets and coagulation in thrombus formation on plaques acutely ruptured by targeted ultrasound treatment: a novel intravital model. J Thromb Haemost 2009;7:152-61.

[91] Dubois C, Panicot-Dubois L, Merrill-Skoloff G, Furie B, Furie BC. Glycoprotein VIdependent and -independent pathways of thrombus formation in vivo. Blood 2006;107:3902-6.

[92] Hechler B, Nonne C, Eckly A, Magnenat S, Rinckel JY, Denis CV, et al. Arterial thrombosis: relevance of a model with two levels of severity assessed by histologic, ultrastructural and functional characterization. J Thromb Haemost 2010;8:173-84.

[93] Zahid M, Mangin P, Loyau S, Hechler B, Billiald P, Gachet C, et al. The future of glycoprotein VI as an antithrombotic target. J Thromb Haemost 2012;10:2418-27.

[94] Matus V, Valenzuela G, Sáez CG, Hidalgo P, Lagos M, Aranda E, et al. An adenine insertion in exon 6 of human GP6 generates a truncated protein associated with a bleeding disorder in four Chilean families. J Thromb Haemost 2013;11:1751-9.

[95] Jones CI, Bray S, Garner SF, Stephens J, de Bono B, Angenent WGJ, et al. A functional genomics approach reveals novel quantitative trait loci associated with platelet signaling pathways. Blood 2009;114:1405-16.

[96] Johnson AD, Yanek LR, Chen MH, Faraday N, Larson MG, Tofler G, et al. Genomewide meta-analyses identifies seven loci associated with platelet aggregation in response to agonists. Nat Genet 2010;42:608-13.

[97] Nieswandt B, Brakebusch C, Bergmeier W, Schulte V, Bouvard D, Mokhtari-Nejad R, et al. Glycoprotein VI but not $\alpha 2 \beta 1$ integrin is essential for platelet interaction with collagen. EMBO J 2001;20:2120-30.

[98] Kuijpers MJ, Schulte V, Bergmeier W, Lindhout T, Brakebusch C, Offermanns S, et al. Complementary roles of glycoprotein VI and alpha2beta1 integrin in collageninduced thrombus formation in flowing whole blood ex vivo. FASEB J 2003;17:685-7.

[99] Munnix IC, Strehl A, Kuijpers MJ, Auger JM, van der Meijden PE, van Zandvoort MA, et al. The glycoprotein VI-phospholipase $\mathrm{C} \gamma 2$ signaling pathway controls thrombus formation induced by collagen and tissue factor in vitro and in vivo. Arterioscler Thromb Vasc Biol 2005;25:2673-8.

[100] Elvers M, Pozgaj R, Pleines I, May F, Kuijpers MJ, Heemskerk JM, et al. Platelet hyperreactivity and a prothrombotic phenotype in mice with a gain-of-function mutation in phospholipase C $\gamma 2$. J Thromb Haemost 2010;8:1353-63.

[101] Watson SP, Herbert JM, Pollitt AY. GPVI and CLEC-2 in hemostasis and vascular integrity. J Thromb Haemost 2010;8:1456-67.

[102] Siljander PR, Munnix IC, Smethurst PA, Deckmyn H, Lindhout T, Ouwehand WH, et al. Platelet receptor interplay regulates collagen-induced thrombus formation in flowing human blood. Blood 2004;103:1333-41.

[103] Lecut C, Schoolmeester A, Kuijpers MJ, Broers JLV, van Zandvoort MA Vanhoorelbeke K, et al. Principal role of glycoprotein VI in $\alpha 2 \beta 1$ and $\alpha$ IIb $\beta 3$ activation during collagen-induced thrombus formation. Arterioscler Thromb Vasc Biol 2004;24:1727-33.

[104] Matsumoto Y, Takizawa H, Nakama K, Gong X, Yamada Y, Tandon NN, et al. Ex vivo evaluation of anti-GPVI antibody in cynomolgus monkeys: dissociation between anti-platelet aggregatory effect and bleeding time. Thromb Haemost 2006;96:167-75.

[105] Massberg S, Konrad I, Bultmann A. Schulz C, Munch G, Peluso M, et al. Soluble glycoprotein VI dimer inhibits platelet adhesion and aggregation to the injured vessel wall in vivo. FASEB J 2004;18:397-9.

[106] Ungerer M, Rosport K, Bultmann A, Piechatzek R, Uhland K, Schlieper P, et al. Novel antiplatelet drug revacept (dimeric glycoprotein VI-Fc) specifically and efficiently inhibited collagen-induced platelet aggregation without affecting general hemostasis in humans. Circulation 2011;123:1891-9.

[107] Suzuki-Inoue K, Inoue O, Ozaki Y. Novel platelet activation receptor CLEC-2: from discovery to prospects. J Thromb Haemost 2011;9(Suppl. 1):44-55.

[108] Navarro-Nunez L, Langan SA, Nash GB, Watson SP. The physiological and pathophysiological roles of platelet CLEC-2. Thromb Haemost 2013;109:991-8.

[109] Parguina AF, Alonso J, Rosa I, Velez P, Gonzalez-Lopez MJ, Guitian E, et al. A detailed proteomic analysis of rhodocytin-activated platelets reveals novel clues on the CLEC-2 signalosome: implications for CLEC-2 signaling regulation. Blood 2012;120: e117-26.

[110] May F, Hagedorn I, Pleines I, Bender M, Vogtle T, Eble J, et al. CLEC-2 is an essential platelet-activating receptor in hemostasis and thrombosis. Blood 2009;114:3464-72.

[111] Bender M, May F, Lorenz V, Thielmann I, Hagedorn I, Finney BA, et al. Combined in vivo depletion of glycoprotein VI and C-type lectin-like receptor 2 severely compromises hemostasis and abrogates arterial thrombosis in mice. Arterioscler Thromb Vasc Biol 2013;33:926-34.

[112] Moser M, Nieswandt B, Ussar S, Pozgajova M, Fässler R. Kindlin-3 is essential for integrin activation and platelet aggregation. Nat Med 2008;14:325-30.

[113] Petrich BG, Marchese P, Ruggeri ZM, Spiess S, Weichert RA, Ye F, et al. Talin is required for integrin-mediated platelet function in hemostasis and thrombosis. J Exp Med 2007;204:3103-11.

[114] Nieswandt B, Varga-Szabo D, Elvers M. Integrins in platelet activation. J Thromb Haemost 2009;7(Suppl. 1):206-9.

[115] Shattil SJ. Signaling through platelet integrin $\alpha$ IIb $\beta 3$ : inside-out, outside-in sideways. Thromb Haemost 1999;82:318-25.
[116] Van der Meijden PE, Feijge MA, Swieringa F, Gilio K, Nergiz-Unal R, Hamulyak K, et al. Key role of integrin $\alpha \mathrm{Ilb} \beta 3$ signaling to Syk kinase in tissue factor-induced thrombin generation. Cell Mol Life Sci 2012;69:3481-92.

[117] Nurden AT, Fiore M, Nurden P, Pillois X. Glanzmann thrombasthenia: a review of ITGA2B and ITGB3 defects with emphasis on variants, phenotypic variability, and mouse models. Blood 2011;118:5996-6005.

[118] Hodivala-Dilke KM, McHugh KP, Tsakiris DA, Rayburn H, Crowley D Ullman-Cullere $\mathrm{M}$, et al. Beta3-integrin-deficient mice are a model for Glanzmann thrombasthenia showing placental defects and reduced survival. J Clin Invest 1999;103:229-38.

[119] Tronik-Le Roux D, Roullot V, Poujol C, Kortulewski T, Nurden P, Marguerie G. Thrombasthenic mice generated by replacement of the integrin $\alpha$ Ilb gene: demonstration that transcriptional activation of this megakaryocytic locus precedes lineage commitment. Blood 2000;96:1399-408.

[120] Malinin NL, Zhang L, Choi J, Ciocea A, Razorenova O, Ma YQ, et al. A point mutation in KINDLIN3 ablates activation of three integrin subfamilies in humans. Nat Med 2009; 15:313-8.

[121] Svensson L, Howarth K, McDowall A, Patzak I, Evans R, Ussar S, et al. Leukocyte adhesion deficiency-III is caused by mutations in KINDLIN3 affecting integrin activation. Nat Med 2009;15:306-12.

[122] Leopold JA. Small-molecule glycoprotein IIb/IIIa antagonists and bleeding risk in women. Too much of a good thing? Circulation 2006;114:1344-6.

[123] Muniz-Lozano A, Rollini F, Franchi F, Angiolillo DJ. Update on platelet glycoprotein IIb/IIla inhibitors: recommendations for clinical practice. Ther Adv Cardiovasc Dis 2013;7:197-213.

[124] Armstrong PC, Peter K. GPIIb/IIla inhibitors: from bench to bedside and back to bench again. Thromb Haemost 2012;107:808-14.

[125] Van de Vijver E, de Cuyper IM, Gerrits AJ, Verhoeven AJ, Seeger K, Gutierrez L, et al Defects in Glanzmann thrombasthenia and LAD-III (LAD-1/v) syndrome: the role of integrin $\beta 1$ and $\beta 3$ in platelet adhesion to collagen. Blood 2012;119:583-6.

[126] Kuijpers MJ, Pozgajova M, Cosemans JM, Munnix IC, Eckes B, Nieswandt B, et al. Role of murine integrin $\alpha 2 \beta 1$ in thrombus stabilization and embolization: contribution of thromboxane $A_{2}$. Thromb Haemost 2007;98:1072-80.

[127] Chen J, Diacovo TG, Grenache DG, Santoro SA, Zutter MM. The $\alpha 2$ integrin subunitdeficient mouse: a multifaceted phenotype including defects of branching morphogenesis and hemostasis. Am J Pathol 2002;161:337-44.

[128] Grüner S, Prostredna M, Aktas B, Moers A, Schulte V, Krieg T, et al. Antiglycoprotein VI treatment severely compromises hemostasis in mice with reduced $\alpha 2 \beta 1$ levels or concomitant aspirin therapy. Circulation 2004;110:2946-51.

[129] Petzold T, Ruppert R, Pandey D, Barocke V, Meyer H, Lorenz M, et al. $\beta 1$ integrinmediated signals are required for platelet granule secretion and hemostasis in mouse. Blood 2013;122:2723-31.

[130] Nieuwenhuis HK, Akkerman JW, Houdijk WP, Sixma JJ. Human blood platelets showing no response to collagen fail to express surface glycoprotein Ia. Nature 1985;318:470-2.

[131] Kehrel B, Balleisen L, Kokott R, Mesters R, Stenzinger W, Clemetson KJ, et al. Deficiency of intact thrombospondin and membrane glycoprotein la in platelets with defective collagen-induced aggregation and spontaneous loss of disorder. Blood 1988;71:1074-8.

[132] Schaff M, Tang C, Maurer E, Bourdon C, Receveru N, Eckly A, et al. Integrin $\alpha 6 \beta 1$ is the main receptor for vascular laminins and plays a role in platelet adhesion, activation, and arterial thrombosis. Circulation 2013;128:541-52.

[133] Versteeg HH, Heemskerk JW, Levi M, Reitsma PH. New fundamentals in hemostasis. Physiol Rev 2013;93:327-58.

[134] Jackson SP. The growing complexity of platelet aggregation. Blood 2007;109:5087-95

[135] Brass LF, Wannemacher KM, Ma P, Stalker TJ. Regulating thrombus growth and stability to achieve an optimal response to injury. J Thromb Haemost 2011;9(Suppl. 1):66-75.

[136] Cosemans JM, Angelillo-Scherrer A, Mattheij NJ, Heemskerk JW. The effects of arterial flow on platelet activation, thrombus growth, and stabilization. Cardiovasc Res 2013;99:342-52.

[137] Watson SP, Lowe GC, Lordkipanidze M, Morgan NV. Genotyping and phenotyping of platelet function disorders. J Thromb Haemost 2013;11(Suppl. 1):351-63.

[138] Deppermann C, Cherpokova D, Nurden P, Schulz JN, Thielmann I, Kraft P, et al. Gray platelet syndrome and defective thrombo-inflammation in Nbeal2-deficient mice. Clin Invest 2013 [in press] http://dx.doi.org/10.1172/JCI69210.

[139] Nylander S, Kull B, Björkman JA, Ulvinge JC, Oakes N, Emanuelsson BM, et al. Human target validation of phosphoinositide 3-kinase (PI3K)B: effects on platelets and insulin sensitivity, using AZD6482 a novel PI3K 3 inhibitor. J Thromb Haemost 2012;10:2127-36.

[140] Mauer AC, Khazanov NA, Levenkova N, Tian S, Barbour EM, Khalida C, et al. Impact of sex, age, race, ethnicity and aspirin use on bleeding symptoms in healthy adults. J Thromb Haemost 2011;9:100-8.

[141] Rydz N, James PD. The evolution and value of bleeding assessment tools. J Thromb Haemost 2013 [in press] http://dx.doi.org/10.1111/j.1538-7836.2012.04923.x.

[142] Rodeghiero F, Tosetto A, Abshire T, Arnold DM, Coller B, James P, et al. ISTH/SSC bleeding assessment tool: a standardized questionnaire and a proposal for a new bleeding score for inherited bleeding disorders. J Thromb Haemost 2010;8:2063-965.

[143] Lowe GC, Lordkipanidzé M, Watson SP, UK GAPP study group. Utility of the ISTH bleeding assessment tool in predicting platelet defects in participants with suspected inherited platelet function disorders. J Thromb Haemost 2013;11:1663-8.

[144] Mehran R, Rao SV, Bhatt DL, Gibson CM, Caixeta A, Eikelboom J, et al. Standardized bleeding definitions for cardiovascular clinical trials. Circulation 2011;123:2736-47.

[145] Harrison P, Mackie I, Mumford A, Briggs C, Liesner R, Winter M, et al. Guidelines for the laboratory investigation of heritable disorders of platelet function. $\mathrm{Br}$ Haematol 2011;155:30-44. 
[146] Cattaneo M, Cerletti C, Harrison P, Hayward CP, Kenny D, Nugent D, et al. Recommendations for the standardization of light transmission aggregometry: a consensus of the working party from the Platelet Physiology Subcommittee of SSC/ISTH. J Thromb Haemost 2013 [in press] http://dx.doi.org/10.1111/jth.12231.

[147] Hayward CP, Harrison P, Cattaneo M, Ortel TL, Rao AK. Platelet function analyzer (PFA)-100 closure time in the evaluation of platelet disorders and platelet function. J Thromb Haemost 2006;4:312-9.

[148] Sladky JL, Klima J, Grooms L, Kerlin BA, O'Brien SH. The PFA-100 (R) does not predict delta-granule platelet storage pool deficiencies. Haemophilia 2012;18:626-9.

[149] Goodall AH, Appleby J. Flow-cytometric analysis of platelet-membrane glycoprotein expression and platelet activation. Methods Mol Biol 2004;272:225-53.

[150] Fox SC, May JA, Shah A, Neubert U, Heptinstall S. Measurement of platelet Pselectin for remote testing of platelet function during treatment with clopidogrel and/or aspirin. Platelets 2009;20:250-9.

[151] Roest M, van Holten T, Remijn J. Platelet activation test in unprocessed blood to monitor platelet concentrates and whole blood of thrombocytopenic patients. Transfus Med Hemother 2013;40:117-25

[152] Vanschoonbeek K, Feijge MA, van Kampen RJ, Kenis H, Hemker HC, Giesen PL, et al. Initiating and potentiating roles of platelets in tissue factor-induced thrombin generation in the presence of plasma: subject-dependent variation in thrombogram characteristics. J Thromb Haemost 2004:2:476-84

[153] Subcommittee on Control of Anticoagulation of the SSC of the ISTH. Towards a recommendation for the standardization of the measurement of platelet-dependent thrombin generation. J Thromb Haemost 2011;9:1859-61.
[154] Ninivaggi M, Apitz-Castro R, Dargaud Y, de Laat B, Hemker HC, Lindhout T. Wholeblood thrombin generation monitored with a calibrated automated thrombogrambased assay. Clin Chem 2012;58:1252-9.

[155] Berny MA, Munnix IC, Auger JM, Schols SE, Cosemans JM, Panizzi P, et al. Spatial distribution of factor $\mathrm{Xa}$, thrombin, and fibrin(ogen) on thrombi at venous shear. PLoS One 2010;5:e10415.

[156] Roest M, Reininger A, Zwaginga JJ, King MR, Heemskerk JW. Flow chamber-based assays to measure thrombus formation in vitro: requirements for standardization. J Thromb Haemost 2011;9:2322-4.

[157] Van Kruchten R, Cosemans JM, Heemskerk JW. Measurement of whole blood thrombus formation using parallel-plate flow chambers: a practical guide. Platelets 2012;23:229-42.

[158] Cattaneo M. New P2Y 12 inhibitors. Circulation 2010;121:171-9.

[159] Janssen PW, ten Berg JM. Platelet function testing and tailored antiplatelet therapy. J Cardiovasc Transl Res 2013;6:316-28.

[160] Tantry US, Bonello L, Aradi D, Price MJ, Jeong YH, Angiolillo DJ, et al. Consensus and update on the definition of on-treatment platelet reactivity to ADP associated with ischemia and bleeding. J Am Coll Cardiol 2013;62:2261-73.

[161] Tantry US, Gurbel PA. Assessment of oral antithrombotic therapy by platelet function testing. Nat Rev Cardiol 2011;8:572-9.

[162] Michelson AD. Platelets. Amsterdam: Elsevier; 2007.

[163] Burkhart JM, Vaudel M, Gambaryan S, Radau S, Walter U, Martens L, et al. The first comprehensive and quantitative analysis of human platelet protein composition allows the comparative analysis of structural and functional pathways. Blood 2012;120:e73-82. 